\title{
OPEN Evaluation of an in vitro assay to screen for the immunotoxic potential of chemicals to fish
}

\author{
Kristina Rehberger ${ }^{1 凶}$, Beate I. Escher ${ }^{2,3}$, Andreas Scheidegger ${ }^{4}$, Inge Werner ${ }^{5}$ \& \\ Helmut Segner ${ }^{1}$
}

A wide variety of environmental contaminants has been shown to disrupt immune functions of fish and may compromise their defense capability against pathogens. Immunotoxic effects, however, are rarely considered in ecotoxicological testing strategies. The aim of this study was to systematically evaluate the suitability of an in vitro immuno-assay using selected fish immune parameters to screen for chemicals with known immunotoxic potential and to differentiate them from non-immunotoxicants. Non-stimulated and lipopolysaccharide-stimulated head kidney leukocytes of rainbow trout (Oncorhynchus mykiss) were exposed for $3 \mathrm{~h}$ or $19 \mathrm{~h}$ to chemicals with different modes of action. As immune parameters, phagocytosis activity, oxidative burst activity and cytokine transcription (IL-16,TNF $\alpha, I L-10$ ) were examined, accompanied by in silico modelling. The immunotoxicants dexamethasone, benzo(a)pyrene, ethinylestradiol and bisphenol A significantly altered the immune parameters at non-cytotoxic concentrations whereas diclofenac had only weak effects. However, the two baseline chemicals with no known immunotoxic potential, butanol and ethylene glycol, caused significant effects, too. From our results it appears that the in vitro fish leukocyte assay as performed in the present study has only a limited capacity for discriminating between immunotoxicants and non-immunotoxicants.

A wide variety of environmental contaminants has been shown to disrupt immune functions of wildlife species. Such immunotoxic activities bear ecological relevance since efficient immunocompetence is a critical fitness determinant enabling the organism to survive, to minimize the fitness costs of infection and to maintain good growth and reproduction ${ }^{1-5}$. For teleost fish populations living in polluted environments, numerous field observations indicate alterations of immune parameters and/or increased disease incidences ${ }^{6-13}$. Environmental contaminants that are known to disrupt the immune system of fish include dioxin-like chemicals or polycyclic aromatic hydrocarbons ${ }^{14-21}$, endocrine-disrupting compounds ${ }^{22-29}$ and pharmaceuticals like the pain killer, diclofenac (DCF) or the anti-inflammatory drug, dexamethasone (Dex $)^{30-33}$.

Valid diagnostic and testing methods are crucial for assessing the hazard and risk arising from immunotoxic chemicals. In human toxicology, regulatory guidelines containing standardized and validated methods for the assessment of immunotoxic activities of chemicals have evolved from the $\left.1980 \mathrm{~s}^{(\mathrm{cf} .}{ }^{34-37}\right)$. In line with the recent paradigm shift in toxicology (Toxicology in the twenty-first century ${ }^{38}$ ), increasing attention is given to the use of in vitro assays ${ }^{39-42}$. Although they cannot provide a definitive assessment of adverse immune effects, they can screen potential immunotoxic activities and prioritize positive compounds for further testing (e.g. ${ }^{40,41,43,44}$ ).

We recently reviewed the literature for tests and endpoints used in immunotoxicity studies with fish ${ }^{45}$. The most frequently analyzed immune parameters were (I) phagocytosis activity (II) respiratory burst activity and (III) immune genes, mainly immune mediators like cytokines at mRNA level. Phagocytosis and oxidative burst are of physiological importance since they are key mechanisms of the innate immune system, which is of particular relevance in fish and, additionally, is well conserved across species. Randelli et al. ${ }^{46}$ mentioned phagocytosis and respiratory burst activity as suitable marker for fish innate immunity and Fournier et al ${ }^{47}$ highlighted the phagocytosis assay as a suitable biomarker for immunotoxic effects in wildlife populations. The most frequently measured immune genes in fish immunotoxicity studies were cytokines, i.e. interleukins (IL) and tumor necrosis factor $(\mathrm{TNF})^{45}$. Cytokines are important signaling proteins orchestrating the immune response ${ }^{48}$. Among the

${ }^{1}$ Centre for Fish and Wildlife Health, Vetsuisse Faculty, University of Bern, Bern, Switzerland. ${ }^{2}$ UFZ-Helmholtz Centre for Environmental Research, Leipzig, Germany. ${ }^{3}$ Centre for Applied Geoscience, Eberhard Karls University Tübingen, Tübingen, Germany. "Eawag: Swiss Federal Institute of Aquatic Science and Technology, Dübendorf, Switzerland. ${ }^{5}$ Swiss Centre for Applied Ecotoxicology, Eawag, Dübendorf, Switzerland. ${ }^{\square}$ email: kristina.rehberger@vetsuisse.unibe.ch 


\begin{tabular}{|c|c|c|c|c|c|}
\hline Test chemical & $\begin{array}{l}\text { Test concentrations } \\
\text { (nominal) }\end{array}$ & MIE/MoA & $\begin{array}{l}\text { Reference supporting the } \\
\text { MIE/MoA in fish }\end{array}$ & $\begin{array}{l}\text { Reported immunotoxic } \\
\text { activity in fish }\end{array}$ & $\begin{array}{l}\text { Reference supporting the } \\
\text { immunotoxic action in fish }\end{array}$ \\
\hline Dexamethasone (Dex) & $\begin{array}{l}0,1,5,10 \mu \mathrm{M} \text { solvent: } \\
\mathrm{MeOH}\end{array}$ & GR & 124,125 & Yes & $31-33$ \\
\hline Diclofenac (DCF) & $0,1,5,10,50 \mu \mathrm{M}$ & COX & 107 & Yes & 30,32 \\
\hline Benzo(a)pyrene (BaP) & $\begin{array}{l}0,0.1,0.5,1 \mu \mathrm{M} \text { solvent: } \\
\text { AcN }\end{array}$ & AhR and via metabolites & $16-18$ & Yes & $20,71,126,127$ \\
\hline Bisphenol A (BPA) & $0,0.5,1,2.5,5 \mu \mathrm{M}$ & ER, AhR, PPAR, NF- $\kappa B$ & 95,96 & Yes & $97,103,104$ \\
\hline 17a-Ethinylestradiol (EE2) & $\begin{array}{l}0,0.25,2.5,5 \mu \mathrm{M} \text { solvent: } \\
\text { EtOH }\end{array}$ & ER & $25-27$ & Yes & $22,24,91,128$ \\
\hline Ethylene glycol (EG) & $0,10,25,50,75 \mathrm{mM}$ & $\begin{array}{l}\text { polar narcotic; Verhaar } \\
\text { class } 2\end{array}$ & 129 & No & - \\
\hline 1-Butanol (But) & $0,2.5,5,7.5,10 \mathrm{mM}$ & $\begin{array}{l}\text { narcotic/baseline; Verhaar } \\
\text { class } 1\end{array}$ & $130-132$ & No & - \\
\hline $\begin{array}{l}\text { 1,2,4-Trichlorobenzene } \\
(\mathrm{TCB})^{*}\end{array}$ & $\begin{array}{l}0,2.5,7.5,25 \mu \mathrm{M} \text { solvent: } \\
\text { EtOH }\end{array}$ & $\begin{array}{l}\text { narcotic/baseline; Verhaar } \\
\text { class } 1\end{array}$ & $130-135$ & No & - \\
\hline
\end{tabular}

Table 1. Nominal concentrations of chemicals for assessing the immune parameters, and their molecular initiating event (MIE)/mode of action (MoA). MeOH methanol, AcN acetonitrile, EtOH ethanol, GR glucocorticoid receptor, $C O X$ cyclooxygenase, $A h R$ aryl hydrocarbon receptor, ER estrogen receptor, $P P A R$ peroxisome proliferator-activated receptor, $N F-\kappa B$ nuclear factor kappa-light-chain-enhancer of activated $B$ cells. ${ }^{\star T C B}$ : the immuno-assay was conducted but results were excluded retrospectively since QASR modelling revealed a loss to air of about $90 \%$.

pro-inflammatory cytokines, IL-1 was evaluated most frequently in fish immunotoxicity studies; among the antiinflammatory cytokines, it was IL- $10^{45}$. All these parameters used in fish immunotoxicity studies-phagocytosis activity, oxidative burst activity, transcription of cytokines-can principally be assessed in in vitro assays using isolated fish leukocytes. Such an assay therefore could be a prime candidate for screening of chemicals with immunotoxic potential in fish. However, a systematic evaluation of the ability of an in vitro fish leukocyte assay to detect immunotoxicants and to discriminate them from non-immunotoxicants has not been undertaken to date.

The aim of the present study was to examine if an in vitro fish leukocyte assay is a suitable tool to screen for immunotoxic potentials of environmental chemicals to fish. We hypothesised that at least one immune parameter measured in this assay-phagocytosis, respiratory burst activity or cytokine transcripts-would be responsive to immunotoxicants while none of the immune parameters would respond to non-immunotoxicants (Table 1). We used leukocytes isolated from the head kidney (HK, a major fish immune organ) of female, non-exposed rainbow trout (Oncorhynchus mykiss). Since the immune system reactivity can differ between the resting and activated state ${ }^{49}$ evaluations were carried out concurrently with non-stimulated leukocytes and with leukocytes stimulated by bacterial lipopolysaccharide (LPS). Chemical exposure was conducted in vitro for $3 \mathrm{~h}$ or $19 \mathrm{~h}$. The tested immunotoxic chemicals included compounds that interfere with the immune system through different modes of action. All tests were performed at sub-cytotoxic concentrations in order to avoid false positive responses of the immunological parameters caused by adverse effects of high concentrations of test chemicals on cell viability $\left(\mathrm{cf}^{50}\right)$. In vitro effect concentrations were compared with in silico predictions for baseline cytotoxicity ${ }^{51}$ to identify how much more potent the specific effects were in comparison to baseline cytotoxicity ${ }^{52}$. Importantly, the purpose using this in vitro assay was neither to predict adverse outcomes nor toxic effect concentrations in whole fish but to screen for chemicals with immunotoxic potential and to discriminate them from non-immunotoxic chemicals.

\section{Methods}

Test chemicals and reagents. Test chemicals are listed in Table 1 including references providing information on their molecular initiating events (MIE)/mode of action (MoA) as well as references describing the immunotoxic activity of these compounds in fish. Dexamethasone (Dex) was used as reference compound since it is a well-established immunosuppressive agent for fish. Other immunotoxicants were diclofenac (DCF), benzo(a)pyrene $(\mathrm{BaP})$, bisphenol $\mathrm{A}(\mathrm{BPA})$ and 17a-ethinylestradiol (EE2). The selection criteria for the three non-immunotoxic chemicals-ethylene glycol (EG), 1-butanol (But), 1,2,4-trichlorobenzene (TCB)-are provided in Table 1, too. For those chemicals we did not find any indication that they possess an immunotoxic activity (key words for the literature search in the Supplementary Material S1a) and they are categorized as baseline/ narcotic compounds. For trichlorobenzene, the immuno-assay was conducted but the results were excluded retrospectively, since the QASR modelling revealed a loss to air of about $90 \%$. Detailed information on the chemicals and reagents used is provided in Supplementary Material S1b. For the chemical exposure, stock solutions were prepared as followed (chemicals in alphabetic order): benzo(a)pyrene: $1 \mathrm{mM}$ in acetonitrile, stored in aliquots at $-20^{\circ} \mathrm{C}$; bisphenol A: $500 \mu \mathrm{M}$ in medium, stored in aliquots at $-20^{\circ} \mathrm{C}$; butanol: no stock solution prepared; dexamethasone: $25.45 \mathrm{mM}$ in methanol; diclofenac: $5 \mathrm{mM}$ in water, stored in aliquots at $-20{ }^{\circ} \mathrm{C}$; ethinylestradiol: $8 \mathrm{mM}$ in ethanol; ethylene glycol: no stock solution prepared; trichlorobenzene: $27.56 \mathrm{mM}$ in ethanol. The required test concentrations were achieved by dilution with medium. If a solvent was required for preparation of the chemical solutions, a solvent-containing (below $0.1 \%$ ) control was included in the immunoassay in addition to the solvent-free control. Although presented data was normalized to the solvent control (if 
a solvent was used), the solvent-free control was still assessed in the viability assay to exclude toxic effects due to the solvent itself (see Supplementary Material S6).

Terminology. For better reader-friendliness, the phrase "chemicals with immunotoxic potential" is shortened to "immunotoxicants", the phrase "chemicals with no reported immunotoxic potential" to "non-immunotoxicants" through the paper. Besides, in this article we use the terms "immunomodulation" and "immunotoxicity" synonymously. Nevertheless, we are aware that "immunomodulation" would be the more accurate term for chemical-induced alterations of fish immune parameters since such alteration does not necessarily imply an adverse, toxic effect on immunocompetence of the organisms. The term "cytotoxicity" is used to describe an acutely lethal effect of the test chemical on cell viability.

Fish husbandry and leukocyte isolation. Head kidney (HK) leukocytes from all-female, not yet reproductively active rainbow trout (Oncorhynchus mykiss) of $777 \pm 229 \mathrm{~g}$ body weight and $38 \pm 4 \mathrm{~cm}$ total length were used in this study. Fish were obtained from "Pisciculture de Vionnaz Hess SA" (Switzerland) and maintained at the Centre for Fish and Wildlife Health, University of Bern, Switzerland. The experiment was approved by the ethical committee of the Canton of Bern under permit number BE 44/15. The study was performed in accordance with relevant guidelines and regulations. The crucial assay parameters such as cell isolation, cell culture, cell density, incubation times and conditions for measuring phagocytosis, respiratory burst and cytokine transcription, including the steps for qPCR analysis and lipopolysaccharide (LPS) stimulation were optimized in the context of the applied study conditions. The protocol for HK leukocyte isolation was modified from Garduño and $\mathrm{Kay}^{53}$ and Braun-Nesje et al. ${ }^{54}$ : trout were euthanized with an overdose of buffered MS222 (tricaine mesylate) followed by a gill cut. The HK was removed, weighed and mechanically disaggregated using nets of $105 \mu \mathrm{m}$ mesh size. The disaggregation was carried out under sterile conditions in an organ-weight dependent volume of medium (RPMI including $50 \mathrm{mM}$ HEPES and $7 \mathrm{mM} \mathrm{NaHCO}$, $\mathrm{pH}$ 7.4) supplemented with $0.5 \%$ fetal bovine serum (FBS, heat inactivated, charcoal-stripped, sterile) and $10 \mathrm{U} / \mathrm{ml}$ heparin. The resulting suspension was centrifuged ( $450 \mathrm{rcf}, 35 \mathrm{~min}, 4^{\circ} \mathrm{C}$ ) over a discontinuous Percoll gradient with 1.04 and 1.075 density. Leukocytes were collected from the interphase, washed twice $\left(250 \mathrm{rcf}, 10 \mathrm{~min}, 4^{\circ} \mathrm{C}\right)$ with $10 \mathrm{U} / \mathrm{ml}$ heparin supplemented medium and once with non-supplemented medium. Cell number was adjusted to $1 \times 10^{6}$ viable cells $/ \mathrm{ml}$ medium using trypan blue staining and a hemocytometer. Cells were then plated in 96-well plates (outer rows filled with cell-free medium) using medium supplemented with $0.5 \%$ FBS. The cell number per well depended on the effect parameter, see below for details. Cells were incubated overnight in a humid and aerated cell incubator at $17^{\circ} \mathrm{C}$ and further processed the next day.

LPS stimulation and test chemical exposure. The conditions for stimulation were optimized in a series of prior tests using three different sources of LPS (O111:B4, O55:B5 and O26:B6) and beta-glucan and combinations thereof at different concentrations and exposure durations as well as prior and parallel to the chemical exposure (data not shown). Based on those results LPS from Escherichia coli 0111:B4 (final concentration $10 \mu \mathrm{g} / \mathrm{ml} \mathrm{medium}{ }^{55}$ ) was added to half of the wells after the overnight incubation and incubated for $3 \mathrm{~h}$ to activate the immune cells. Subsequently, medium was removed from both non-stimulated and LPS-stimulated cells. Leukocytes were then exposed to a range of concentrations of the test chemicals in fresh, LPS- and FBSfree medium for a short-term $(3 \mathrm{~h})$ or long-term $(19 \mathrm{~h})$ period. Each test chemical was measured in five to seven independent biological replicates $(=$ fish). The numbers of biological replicates (fish n-numbers) utilized for statistical analysis are listed in Supplementary Material S4 for each test chemical and immune parameter. LPS treatment served as positive and quality control (see "Data analysis"). Within each individual biological replicate, leukocyte exposure was performed in three technical replicates (= wells) for each treatment. The values of the technical replicates were averaged for statistical analysis. The amount of HK leukocyte obtained from one fish was quite limited, but we were still able to measure all parameters in each exposure scenario (short- and long-term exposure, without and with LPS stimulation) for one test chemical in parallel. Separate 96-well plates were used for long- and short-term exposure as well as for every parameter assessed.

Cytotoxicity assay to determine cell viability. To avoid interference of cytotoxicity with specific immunotoxic effects we determined the cytotoxic concentration range for each chemical prior to the main experiments. To this end, the cells were exposed for 3 and $19 \mathrm{~h}$ to a concentration series of each test chemical, with and without prior LPS stimulation. During the main experiment, cell viability was monitored in parallel to the immune parameters. Cell viability was measured using Calcein-AM (calcein acetoxymethyl ester, final concentration $1 \mu \mathrm{M}, 30 \mathrm{~min}$ incubation, $1.5 \times 10^{5}$ cells/well, modified from Lilius et al.$^{56}$ ). The value was normalized to the total number of cells as determined by means of DAPl nuclei staining (4',6-diamidino-2-phenylindole dihydrochloride, final $5 \mu \mathrm{g} / \mathrm{ml}, 2 \mathrm{~h}$ incubation). Dye intensity was scanned over the entire well-bottom in a 2300 EnSpire Multilabel Plate Reader (PerkinElmer) at $\lambda 495 \mathrm{~nm} / 517 \mathrm{~nm}$ for Calcein-AM and $\lambda 358 \mathrm{~nm} / 461 \mathrm{~nm}$ for DAPI. Data was normalized against the blanks (cells without dye). Test chemical concentrations that resulted in more than $80 \%$ cell viability (equivalent to $<20 \%$ cytotoxicity, EC20 $0_{\text {Cytotox }}$ ) in the range finding were used to evaluate the immune parameters and to run the in silico modelling in the main experiment.

Phagocytosis activity. The phagocytosis activity was evaluated with a method adapted from Harford et al. ${ }^{57}$. Leukocytes $\left(2.5 \times 10^{5}\right.$ cells/well) were simultaneously exposed to the test chemical and $1 \mu \mathrm{m}$ yellowgreen-fluorescently labeled latex beads (cell:bead ratio of 1:12). Accordingly, cells were allowed to ingest beads for $3 \mathrm{~h}$ or $19 \mathrm{~h}$, depending on the exposure conditions. Afterwards, cells were placed on ice to prevent further phagocytosis. Beads were then added to three wells of non-exposed, control leucocytes which represented the 


\begin{tabular}{|l|l|l|l|}
\hline Gene & Forward primer $\left(\mathbf{5}^{\prime}-\mathbf{3}^{\prime}\right)$ & Reverse primer $\left(\mathbf{5}^{\prime} \mathbf{3}^{\prime} \mathbf{)}\right.$ & References \\
\hline $18 S$ & TGCGGCTTAATTTGACTCAACA & CAACTAAGAACGGCCATGCA & 136 \\
\hline$E F-1 \alpha$ & TGCCCCTGGACACAGAGATT & CCCACACCACCAGCAACAA & 137 \\
\hline$I L-10$ & CTGCTGCTCCTTCGTAGAGG & CTCGTCATTAGCCTCGTAGTAGTCTC & 138 \\
\hline$I L-1 \beta$ & AGTGCTGTGGAAGAACATATAGTGTTG & CATCAGGACCCAGCACTTG & 138 \\
\hline$T N F \alpha 1+2$ & AGGGGACAAACTGTGGACTG & GTGCAAACACACCAAAGAAGTT & 138 \\
\hline
\end{tabular}

Table 2. Primer sequences and corresponding references.

blanks. The blanks were used to correct for potential uptake or attachment of beads to the surface of the cells that may have happened during the short time between placing the cells on ice and the flow cytometry measurement. Next, the supernatant of each well was transferred into an individual $1.5 \mathrm{ml}$ tube and cells were detached from culture plates using trypsin. The resulting cell suspension was added to the supernatant and centrifuged at $200 \mathrm{rcf}$ and $4{ }^{\circ} \mathrm{C}$ for $8 \mathrm{~min}$. The supernatant was discharged by pipetting and cells were re-suspended in fresh chemical- and bead-free medium. Subsequently, 10,000 cells were measured in a flow cytometer. Experiments with dexamethasone, ethinylestradiol and trichlorobenzene were analyzed on a BD FACSCanton II flow cytometer, the other experiments on a BD LSR II which broke during the study, but results were similar for both devices. This was confirmed by repeating a bisphenol A exposure and analyzing it on the BD FACSCanton II.

The percentage of phagocytosis-active cells was determined as follows using the software program FlowJo v10: cells of interest were selected (= gated) in a forward scatter (FSC) vs. side scatter (SSC) plot. Based on their forward and sideward properties, gates were placed around myeloid-like and lymphocyte-like cells as well as a third gate for both cell types together ("all cells"). Within the selection, propidium iodide negative (final concentration $3 \mu \mathrm{M}$ ), single cells (FSC-A vs. FSC-H) that additionally stained for FITC (fluorescein isothiocyanate, detection of the beads) were considered to represent the number of phagocytosis-active cells which ingested at least one bead. Data obtained was normalized against the blanks. The data presented in this study is based on the phagocytic activity of the myeloid-like cell fraction such as granulocytes and macrophages. Initially, the three gates of the FSC-SSC-plot were analyzed individually and data for myeloid-like cells yielded the clearest pattern although results were similar for all approaches. This is in accordance with results of other studies: cells that sense pathogens through receptors such as granulocytes (myeloid-like) are particularly active ingesting foreign particles ${ }^{58}$ even though fish lymphocytes conduct phagocytosis, too ${ }^{59-61}$. Initially, data for myeloid-like cells were additionally analyzed according to the number of ingested beads: (a) one, (b) two or (c) three and more beads. Results obtained were similar to analysis results on phagocytosis independent of the number of ingested beads. Thus, the latter is presented in this article.

Respiratory burst activity. During a respiratory/oxidative burst, leukocytes generate reactive oxygen species (ROS) to attack phagocytosed pathogens. The impact of chemical exposure on the respiratory burst activity of leukocytes was assessed using a nitro blue tetrazolium (NBT) assay adapted from Rymuszka and Adaszek ${ }^{62}$ : after chemical exposure the 96 -well plates were centrifuged ( $300 \mathrm{rcf}, 2 \mathrm{~min})$ and leukocytes $\left(2 \times 10^{5}\right.$ cells/well $)$ were incubated for $2 \mathrm{~h}$ in fresh, chemical-free medium containing $1 \mathrm{mg} / \mathrm{ml} \mathrm{NBT}$. Afterwards, plates were centrifuged (300 rcf, $2 \mathrm{~min}$ ) and medium was replaced by $100 \% \mathrm{MeOH}$ for $2 \mathrm{~min}$. $\mathrm{MeOH}$ was removed after additional centrifugation ( $300 \mathrm{rcf}, 2 \mathrm{~min}$ ). $2 \mathrm{M} \mathrm{KOH}$ and DMSO were added to the dried wells, mixed to dissolve crystals and plates were centrifuged ( $300 \mathrm{rcf}, 2 \mathrm{~min})$. An aliquot $(150 \mu \mathrm{l})$ of the supernatant was transferred into a clean well and photometrically measured at $\lambda 630 \mathrm{~nm}$. Data was normalised against the blanks (cells without NBT).

qRT-PCR analysis of cytokine mRNA transcript levels. To assess the effect of chemical exposure on the cytokine mRNA transcript level ( $I L-1 \beta, T N F \alpha$ and $I L-10)$, quantitative real-time PCR (qRT-PCR) analysis was conducted. In a series of prior tests, we evaluated the suitability of different RNA extraction kit, optimized the RNA extraction, assessed the quality of the extracted RNA by using the bioanalyzer methodology and we optimized the cDNA synthesis as well as the qPCR protocol. For the measurements, the 96 -well plates $\left(2 \times 10^{5}\right.$ cells/well) were centrifuged ( $300 \mathrm{rcf}, 2 \mathrm{~min}$ ) after chemical exposure, medium was removed and plates were subsequently stored at $-80^{\circ} \mathrm{C}$. Only cells from the control and the highest chemical concentration were analyzed. RNA was extracted using the ReliaPrep RNA Cell Miniprep System (Promega) with two modifications: (I) RNA was extracted from pooled cells of two technical replicates per treatment by consecutive centrifugation of replicates on the same extraction column. (II) RNA was eluted from the extraction column using two times $7.5 \mu \mathrm{l}$ nuclease-free water. RNA yield was estimated using the NanoDrop 1000 spectrophotometer (Witec AG). For cDNA synthesis, 100 ng RNA were used and the GoScript Reverse Transcription Mix, Random Primers (Promega) protocol was followed. For qRT-PCR analysis the SYBR-green-type GoTaq qPCR Master Mix (Promega) protocol was applied with the following modifications: hot-start activation $5 \mathrm{~min}$ and 45 cycles. Sample composition are listed in Supplementary Material S1c, primer sequences are listed in Table 2 including references which evaluated the rainbow trout primers in the same lab as in which the present study was conducted. All samples were measured in technical duplicates using the 7500 Fast Real-Time PCR System (Applied Biosystems) and the SDS Software version 1.3.1 (Applied Biosystems). NTCs (negative controls, containing no cDNA but water) and melting curves were carried out for each plate to exclude contamination or erroneous amplification. For data analysis the threshold (i.e. signal exceeds background level) was set at $\mathrm{Ct} 0.2$ and the baseline between cycle 3-15. Calculations were made using the $2^{-\Delta \Delta \mathrm{Ct}}$ method. We analyzed transcript levels of two reference genes, $18 \mathrm{~S}$ 


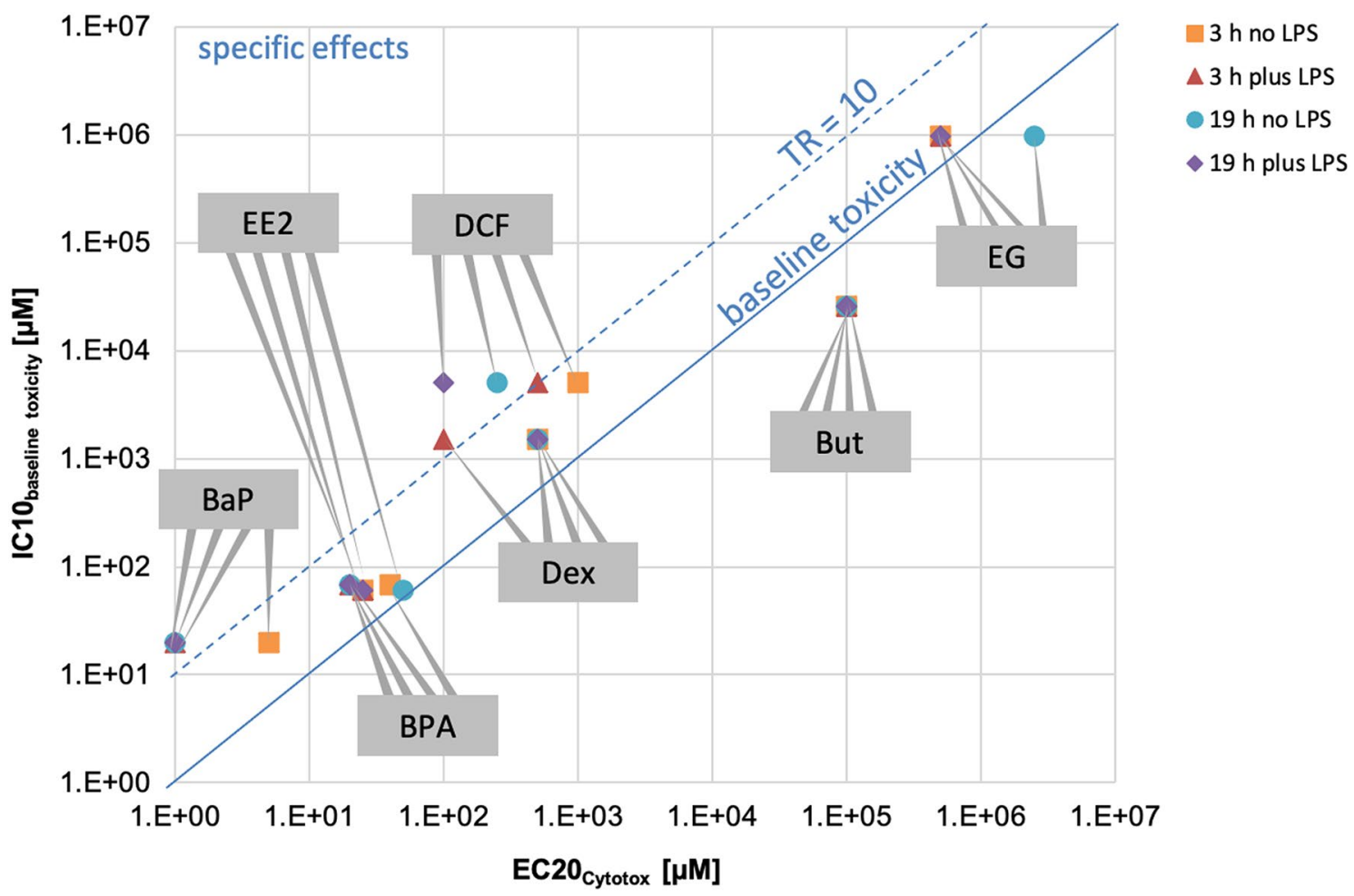

Figure 1. Comparison of the EC20 $0_{\text {Cytotox }}$ for measured cytotoxicity with baseline toxicity predictions

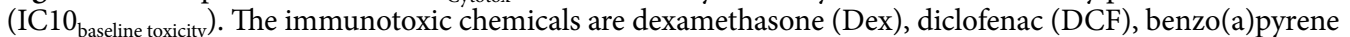
$(\mathrm{BaP})$, bisphenol A (BPA) and ethinylestradiol (EE2), the non-immunotoxicants are ethylene glycol (EG) and butanol (But). For BaP the highest tested concentration was used since all chemical concentrations were in the non-cytotoxic range, thus, the $\mathrm{EC} 20_{\text {Cytotox }}$ was not determinable. $\mathrm{TR} \leq 10$ indicates that cytotoxicity was caused by a non-specific mode of action. $T R$ toxic ratio, $E C$ effect concentration.

and $E F-1 \alpha$. Although expression of both reference genes was stable, $E F-1 \alpha$ expression showed less variability between time points and between treatments and controls, thus data was normalized to $E F-1 \alpha$. Mean $\mathrm{Ct}$ values for $E F-1 \alpha$ are displayed for all test chemicals in Supplementary Material S1d. The effects on cytokine expression are expressed as fold change in relation to the control $(=1)$ of each fish to account for possible variation between fish in the basal expression level.

In silico modelling to determine baseline toxicity and degree of specificity of the effect. In order to confirm if the immune responses were specific or caused by non-specific toxicity (baseline toxicity or narcosis) we predicted the inhibitory concentrations for baseline toxicity of the test chemicals and compared them to their experimentally determined effect concentrations. All baseline toxicants have a critical membrane concentration of approximately $69 \mathrm{mmol} / \mathrm{L}_{\text {membrane lipid }}$ that triggers $10 \%$ cytotoxicity $^{51}$. This critical membrane concentration can be converted to nominal IC10 baseline toxicity with a mass balance model that accounts for the distribution of the chemicals between medium components and uptake into cells and cell membranes ${ }^{51}$. The IC10 baseline toxicity depends on the medium composition and the cell make-up in terms of lipid and protein content. Model input parameters such as protein and lipid content were taken from Fischer et al. ${ }^{63}$ and adapted to the cells and medium used here. The distribution constants between protein and water $D_{\text {proteinw }}$ and between membrane lipids and water $D_{\text {lipw }}$ at $\mathrm{pH} 7.4$ for all test chemicals are listed in the Supplementary Material S2. This model does not account for evaporative losses, so the trichlorobenzene (TCB), whose loss to air might be as large as $90 \%$, was omitted from this analysis. All other chemicals were not expected to be lost to the headspace (calculated according to Escher et al. ${ }^{51}$, data not shown). The model also does not account for sorption to the plastic of well-plates because, as we recently showed, binding to polystyrene is a kinetically controlled process and in presence of sufficient lipids and proteins the loss is negligible for the chemicals tested because the freely dissolved concentration that would bind to the polystyrene is very small ${ }^{64}$. The $\mathrm{EC}^{2} 0_{\mathrm{Cytotox}}$ represents the concentration at which the measured cell viability decreased below $80 \%$-equivalent to $<20 \%$ cytotoxicity (EC: effect concentration). This threshold was used to determine the non-cytotoxic concentrations range of test chemicals of the present study and thus, was used for the in silico modelling, too. This experimentally measured cytotoxicity $\left(\mathrm{EC} 20_{\text {Cytotox }}\right)$ was plotted versus the predicted $\mathrm{IC}_{10} 0_{\text {baseline toxicity }}$ (Fig. 1). The toxic ratio (TR), which expresses the ratio between calculated $\mathrm{IC}_{10} 0_{\text {baseline toxicity }}$ and the measured $\mathrm{EC} 20_{\text {Cytotox }}$ of the present study, was used to identify if the cytotoxicity was caused by a specific MoA $(T R>10)$ or was non-specific $(T R \leq 10){ }^{\text {cf.65. }}$. The specificity ratio (SR) is an indicator of how much more potent the specific effect of the test chemicals is compared to the cytotoxicity $(\mathrm{SR}<10 \text { indicates non-specific action })^{52}$. The SR of the present study was calculated as the ratio of the 
EC20 ${ }_{\text {Cytotox }}$ to the $\mathrm{LOEC}_{\text {immune parameter }}$ The $\mathrm{LOEC}_{\text {immune parameter }}$ corresponds to the lowest concentration for which the chemical-induced effect on an immune parameter, compared to the control, had a $\mathrm{p}$ value $\leq 0.05$ (thus, the LOEC $_{\mathrm{i}}$ was not available for all endpoints and chemicals).

Data analysis. For the final statistical analysis we assumed that the effects of LPS, the exposure period and the level of chemical concentration act additively to measured immune parameters. Usually, synergy and antagonism come from toxicokinetics and it is unlikely that this is noticeable in pure cell culture systems. In addition, a recently published study demonstrated that below $10 \%$ the prediction of concentration addition and independent action are identical ${ }^{66}$. The model applied in the present study includes a different base level of immune system activity for every fish in order to account for differences between the individuals. All other effects are estimated jointly for all fish. The model equation was as follows:

For an immune system activity parameter (or assay) Y, the $i$ th observed value is modeled as

$$
\begin{aligned}
Y_{i}= & \beta_{0}+\sum_{f \in F} \beta_{f} I\left(\text { fish }_{i}=f\right)+\beta_{|F|+1} I\left(\text { time }_{i}=19 \mathrm{~h}\right)+\beta_{|F|+2} I\left(\text { LPS }_{i}=\text { yes }\right) \\
& +\sum_{c \in C} \beta_{|F|+2+c} I\left(\text { conc }_{i}=c\right) \\
& +\beta_{|F|+|C|+3} I\left(\text { time }_{i}=19 \mathrm{~h}\right) I\left(\text { LPS }_{i}=\text { yes }\right) \\
& +\sum_{c \in C} \beta_{|F|+|C|+3+c} I\left(\text { time }_{i}=19 \mathrm{~h}\right) I\left(\text { conc }_{i}=c\right) \\
& +\sum_{c \in C} \beta_{|F|+2|C|+3+c} I\left(\text { LPS }_{i}=\text { yes }\right) I\left(\text { conc }_{i}=c\right)+\varepsilon_{i}
\end{aligned}
$$

where

$$
\varepsilon_{i} \sim N\left(0, \sigma^{2}\right)
$$

All $\beta_{i}$ are parameters to be estimated.

As the effects cannot be seen in isolation, the model includes interaction terms between all effects. This results in a maximum of 17 parameters: one intercept, six for the fish base level, one for the direct LPS effect, one for the effect of the time point, up to three for the concentration level and maximal five for the interactions. A direct interpretation of these model parameters is not intuitive. For this reason, we applied Wald tests to test meaningful linear combinations of the model parameters (e.g. ${ }^{67}$ ). This enabled us to test the difference between

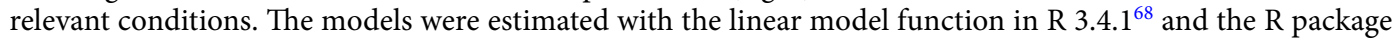
"contrast" ${ }^{\circ 9}$ was applied to test the linear combination of the parameters. The R-code of the model can be found in the Supplementary Material S3. The LPS treatment served as positive and quality control: results were considered valid and included in the data analysis if LPS caused a stimulation of control cells which was higher than in non-stimulated cells and, additionally, exceeded the technical error (R-code step 2 line 23 in Supplementary Material S3). If those criteria were not fulfilled, fish were excluded from the data analysis. The calculated standard deviations for selecting valid data and the resulting $\mathrm{n}$-numbers for each chemical and immune parameter are listed in the Supplementary Material S4. For the qRT-PCR analysis the statistical analysis was done based on the $\Delta \mathrm{Ct}$ values. Diagnostic plots confirmed that the model assumptions were fulfilled well (see Supplementary Material S5). If the p value was below 0.05 statistical significance was accepted.

\section{Results}

The EC20 $0_{\text {Cytotox }}$ value of each exposure scenario (short- and long-term exposure, without and with LPS stimulation) and test chemical was compared with respective predicted $\mathrm{IC}_{10} 0_{\text {baseline toxicity }}$ in Fig. 1 to determine the toxic ratio (TR). The predicted $\mathrm{IC} 10_{\text {baseline toxicity }}$ and the average $\mathrm{EC} 20_{\text {Cytotox }}$ derived from the four exposure scenarios are given in Table 3, the individual values for each exposure scenario are displayed in Fig. 1. A TR $\leq 10$ indicates that the cytotoxicity was caused by a non-specific MoA (see above). Since all TR values were below or very close to $10(\mathrm{TR}=11$ for diclofenac), the cytotoxicity of all chemicals was due to non-specific baseline toxicity (Table 3 ). Results of the cytotoxicity assays are shown in Supplementary Material S6.

Immuno-assay responses to the reference chemical dexamethasone. Dexamethasone was used as reference compound as it is a synthetic derivative of cortisol and a well-established immunosuppressive agent for fish. The immune parameter results for dexamethasone are presented as boxplots in Fig. 2. Detailed results of the statistical analyses are provided in Supplementary Materials S7-S9.

Phagocytosis. Dexamethasone significantly suppressed the phagocytosis activity in a concentration-dependent manner. This was the case for non-stimulated and for LPS-stimulated leukocytes as well as after short- ( $p$ values $<0.05$, not significant for non-stimulated cells after $3 \mathrm{~h}$ of $1 \mu \mathrm{M}$ and $10 \mu \mathrm{M}$ ) and long-term exposure (all $\mathrm{p}$ values $<0.001$, Fig. 2a). LPS caused a significant increase in phagocytosis activity (p value $<0.001$ for $19 \mathrm{~h}$ ).

Respiratory burst activity. Dexamethasone significantly suppressed the respiratory burst activity in a concentration-dependent manner. This was the case for non-stimulated and for LPS-stimulated cells as well as after 


\begin{tabular}{|l|c|c|l|}
\hline Test chemical & IC10 $_{\text {baseline toxicity }}(\boldsymbol{\mu M})$ & Average EC20 $_{\text {Cytotox }}(\boldsymbol{\mu M})$ & TR \\
\hline Dexamethasone (Dex) & 1515 & 400 & 3.8 \\
\hline Diclofenac (DCF) & 5044 & 463 & 10.9 \\
\hline Benzo(a)pyrene (BaP) & 20 & $>2$ & - \\
\hline Bisphenol A (BPA) & 68 & 25 & 2.7 \\
\hline Ethinylestradiol (EE2) & 60 & 31 & 1.9 \\
\hline Ethylene glycol (EG) & 977,000 & $1,000,000$ & 1.0 \\
\hline Butanol (But) & 26,000 & 100,000 & 0.3 \\
\hline
\end{tabular}

Table 3. Predicted $\mathrm{IC} 10_{\text {Cytotox }}$, average $\mathrm{EC} 20_{\text {Cytotox }}$ (derived from short- and long-term exposure, without and with LPS) and the calculated toxic ratio (TR).

short- and long-term exposure ( $\mathrm{p}$ value $<0.05$ for $3 \mathrm{~h}, 1 \mu \mathrm{M}$ without LPS, all other $\mathrm{p}$ values $<0.001$, Fig. $2 \mathrm{~b}$ ). LPS caused a significant stimulation in the respiratory burst activity ( $\mathrm{p}$ value $<0.01$ and $<0.001$ for $3 \mathrm{~h}$ and $19 \mathrm{~h}$ ).

Cytokine transcription. Dexamethasone significantly decreased the mRNA transcript levels of the two proinflammatory cytokines, $I L-1 \beta$ and $T N F \alpha$. This was the case for non-stimulated and for LPS-stimulated cells as well as after short- and long-term exposure (all $\mathrm{p}$ values $<0.001$, except for $I L-1 \beta, 3 \mathrm{~h}$, without LPS (not significant) and with LPS ( $p$ value $<0.01$; Fig. $2 c, d)$ ). Transcription of the anti-inflammatory cytokine $I L-10$ was significantly reduced in the short-term exposure scenario with non-stimulated cells ( $p$ value $<0.05$ ). For the long-term exposure, the $I L-10 \mathrm{mRNA}$ level was significantly increased in stimulated ( $\mathrm{p}$ value $<0.01$ ) and non-stimulated ( $\mathrm{p}$ value $<0.05$ ) leukocytes (Fig. 2e). LPS caused a significant induction of the gene transcription for $I L-10$ ( $\mathrm{p}$ value $<0.01$ after $19 \mathrm{~h}$ ) and $I L-1 \beta$ ( $\mathrm{p}$ value $<0.001$ and $<0.05$ for $3 \mathrm{~h}$ and $19 \mathrm{~h}$ ).

Immuno-assay responses to all test chemicals. Results of all test chemicals are summarized in Fig. 3 and provided in detail as boxplots in Supplementary Material S10. Detailed results of the statistical analyses are provided in Supplementary Material S7-S9 and additional information on the response pattern analysis is described in Supplementary Material S11.

Phagocytosis. Of the substances known to modulate the fish immune system, the compounds dexamethasone (see above), ethinylestradiol (EE2, p values $<0.01$ and $<0.001$ for $3 \mathrm{~h}$ and $19 \mathrm{~h}$ ) and bisphenol A (BPA, $\mathrm{p}$ value $<0.05$ for $19 \mathrm{~h}$ ) significantly inhibited the phagocytosis activity (Fig. 3, column 2 and 3). For diclofenac (DCF) and benzo(a)pyrene (BaP), a trend towards reduced phagocytosis was observed (Fig. 3, column 2 and 3 ). Exposure to the non-immunotoxicant ethylene glycol (EG) resulted in a significant stimulation of phagocytosis activity ( $\mathrm{p}$ values $<0.001$ and $<0.05$ for $3 \mathrm{~h}$ and $<0.001$ and $<0.01$ for $19 \mathrm{~h}$ ). Butanol, in contrast, caused a significant inhibition of phagocytosis activity ( $\mathrm{p}$ values $<0.01$ and $<0.001$ for $3 \mathrm{~h}$ and twice $<0.001$ for $19 \mathrm{~h}$ ). In general, the phagocytosis activity of leukocytes in all experiments was significantly higher after long-term than short-term exposure ( $p$ value $<0.001$; S7: no. $3,4,11,12$ ), but this was independent of the general response pattern, i.e. if the test chemical lowered phagocytosis activity after short-term exposure, it also did after long-term exposure (Fig. 3). LPS treatment significantly increased phagocytosis activity in all long-term treatments (Fig. 3, column 1; $\mathrm{p}$ values $<0.001$ except BPA and But with $\mathrm{p}$ values $<0.05)$.

Respiratory burst activity. Benzo(a)pyrene (p values $<0.001$ for $3 \mathrm{~h} ;<0.01$ and $<0.05$ for $19 \mathrm{~h}$ ) and bisphenol A ( $\mathrm{p}$ values $<0.001$ and $<0.05$ for $3 \mathrm{~h}$; twice $<0.001$ for $19 \mathrm{~h}$ ) significantly increased respiratory burst activity (Fig. 3 , column 2 and 3). In contrast, ethinylestradiol ( $p$ values $<0.001$ except $p$ value $<0.01$ for non-stimulated cells, $3 \mathrm{~h}$ ) and dexamethasone (see above) exposure resulted in a significant inhibition of respiratory burst activity without and with LPS stimulation at both time points. Diclofenac had no significant effects. The non-immunotoxicants, ethylene glycol ( $\mathrm{p}$ value $<0.05$ for stimulated cells, $3 \mathrm{~h} ;<0.05$ and $<0.01$ for $19 \mathrm{~h}$ ) and butanol ( $\mathrm{p}$ value $<0.01$ for stimulated cells, $3 \mathrm{~h} ;<0.05$ and $<0.001$ for $19 \mathrm{~h}$ ), resulted in a significant inhibition of respiratory burst activity for both exposure periods. This effect was stronger in LPS-stimulated leukocytes. LPS significantly stimulated the respiratory activity ( $\mathrm{p}$ values $<0.05$ for But and EE2 $(19 \mathrm{~h}), \mathrm{p}$ values $<0.01$ for BPA $(3 \mathrm{~h}), \mathrm{EE} 2(3 \mathrm{~h}), \mathrm{BaP}$ (19 h), p values $<0.001$ for EG; Fig. 3, column 1).

Cytokine transcription. For $I L-1 \beta$ transcription, significant inhibitions were detected after exposure to dexamethasone (see above), benzo(a)pyrene ( $\mathrm{p}$ value $<0.001$ for stimulated cells, $19 \mathrm{~h}$ ), bisphenol A ( $\mathrm{p}$ values $<0.01$ for non-stimulated cells at $3 \mathrm{~h},<0.001$ and $<0.05$ for $19 \mathrm{~h}$ ) and ethinylestradiol (p values $<0.05$ and $<0.01$ for $19 \mathrm{~h}$ ) as well as after exposure to ethylene glycol ( $\mathrm{p}$ values $<0.001$ for stimulated cells, $19 \mathrm{~h}$ ) and butanol ( $\mathrm{p}$ values $<0.01$ and $<0.001$ for $19 \mathrm{~h}$ ). The inhibition was more pronounced after long-term exposure than after short-term exposure (Fig. 3, column 2 and 3). TNF $\alpha$ transcription was significantly stimulated by butanol, after $3 \mathrm{~h}$ in non-stimulated cells ( $\mathrm{p}$ value $<0.01$ ) but inhibited by dexamethasone (see above). The mRNA transcript level of $I L-10$ was significantly altered by dexamethasone (see above) and increased in response to bisphenol A ( $\mathrm{p}$ value $<0.05$ for stimulated cells, $3 \mathrm{~h}$ ) and diclofenac ( $\mathrm{p}$ value $<0.05$ for non-stimulated cells, $19 \mathrm{~h}$ ). 

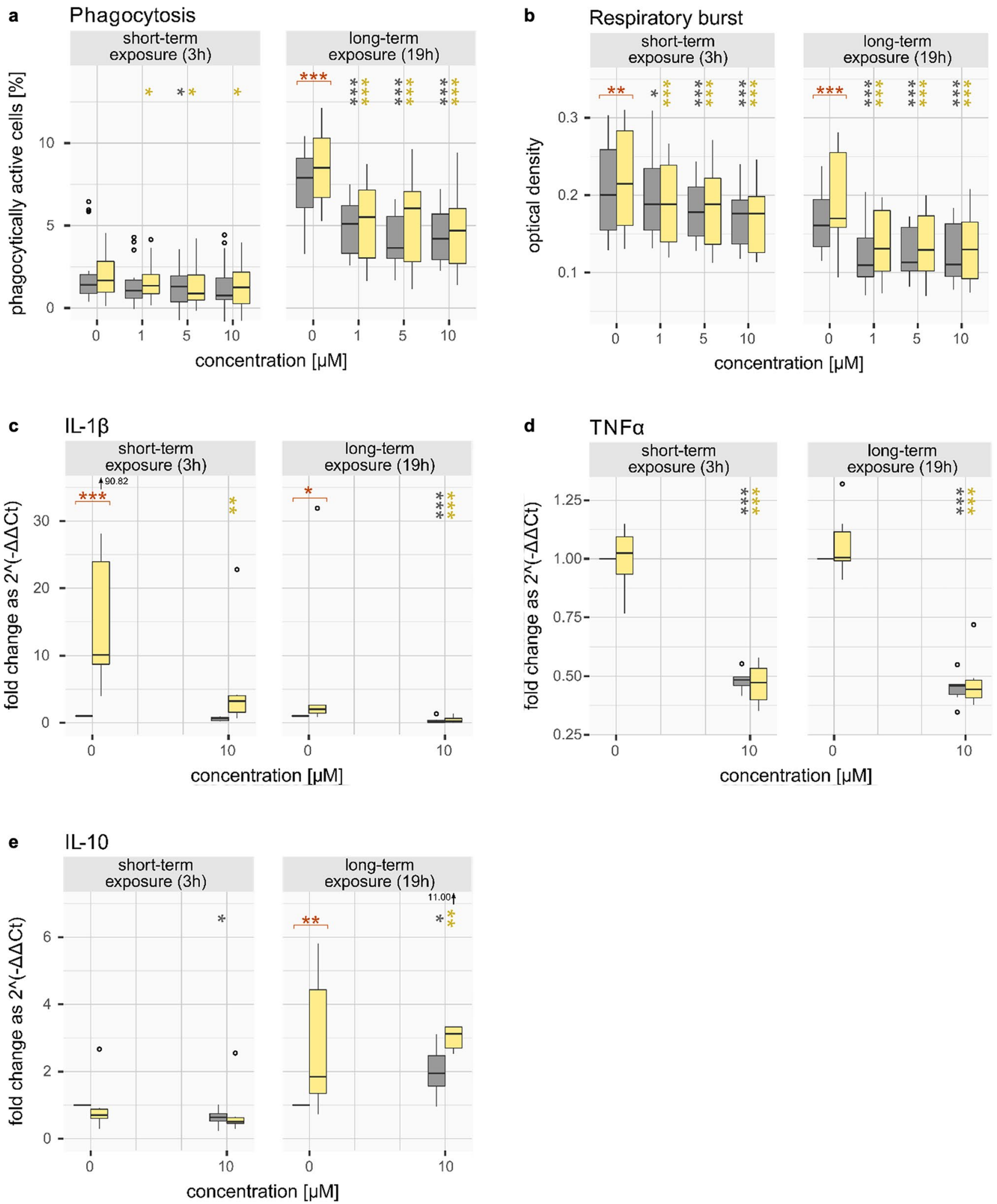

Figure 2. Effects of the reference compound dexamethasone on the immune parameters: phagocytosis (a), respiratory burst (b) and the mRNA transcript levels of $I L-1 \beta(\mathbf{c}), T N F \alpha(\mathbf{d})$ and $I L-10(\mathbf{e})$. Results are shown after short- and long-term exposure with dexamethasone-without (gray) or with (yellow) previous LPS stimulation. Significant differences of the chemical treatments compared to the respective controls are indicated with gray or yellow asterisks, respectively. Significant differences of the control without LPS compared to the control with LPS are indicated with orange asterisks. p values $<0.001$ for $^{\star * *} ;<0.01$ for $^{\star *}$ and $<0.05$ for ${ }^{*}$. 


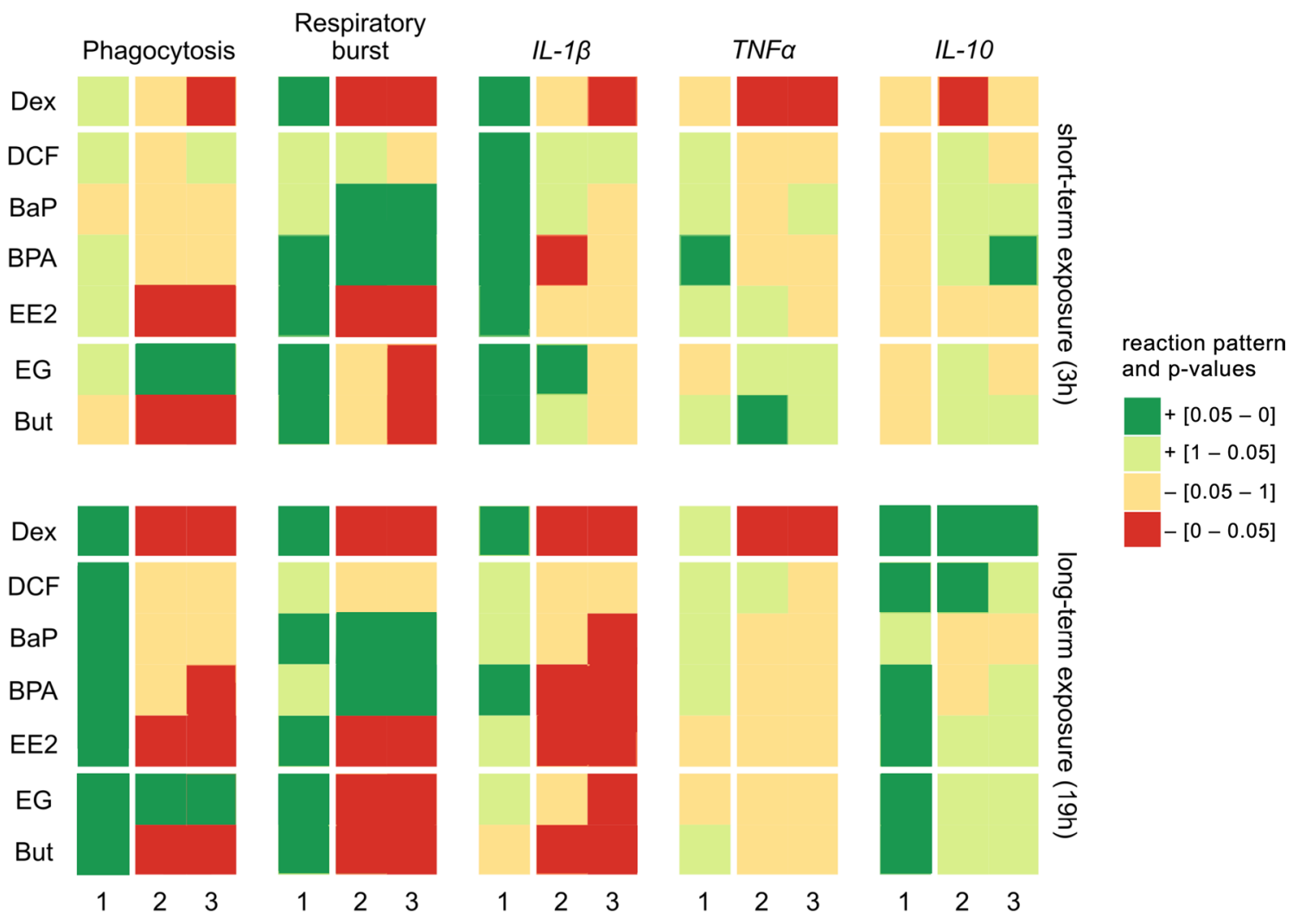

Figure 3. Overview of the in vitro immuno-assay results. Depictured are the results for the comparison of the LPS-stimulated control to the non-stimulated control (column 1 of each immune parameter) and the results for the comparison of the highest applied chemical concentration without (column 2) and with LPS stimulation (column 3) compared to the control without or with LPS stimulation, respectively. Data is displayed for short(top) and long-term (bottom) chemical exposure separately. Colors represent the $\mathrm{p}$ values of the comparisons with underlying decreasing effects in red and for increasing effects in green in relation to the corresponding control. If the $\mathrm{p}$ value was below 0.05 , statistical significance was accepted. The reference compound dexamethasone (Dex), the other immunotoxicants ( $D C F$ diclofenac, BaP benzo(a)pyrene, BPA bisphenol A and EE2 ethinylestradiol) and the non-immunotoxicants ( $E G$ ethylene glycol and But butanol) were clustered with white dividing lines. A detailed, color-blind-, print-friendly version can be found in Supplementary Material S12.

The $\mathrm{LOEC}_{\text {immune parameter }}$ were compared with the respective $\mathrm{EC} 20_{\text {Cytotox }}$ for each exposure scenario (short- and long-term exposure, without and with LPS stimulation) to determine the specific ratio (SR, Fig. 4; numerical values listed in Table 4). The SR indicates how much more potent the immunotoxic activity of the test chemicals is compared to its cytotoxic activity. The average $\mathrm{LOEC}_{\text {immune parameter }}$ of the four exposure scenarios (short- and long-term exposure, without and with LPS stimulation) is given for each immune parameter and test chemical in Table 4, the average EC20 $0_{\text {Cytotox }}$ for the four exposure scenarios in Table 3 . The reference compound dexamethasone acted highly specific on the phagocytosis and respiratory burst activity, as indicated by SR $>100$. Almost all other chemicals showed an SR $>10$, being moderately specific on the phagocytosis (except BPA with $S R=8$ ). For respiratory burst activity, SRs were lower than for phagocytosis activity, but mostly above 10. In contrast, SR values for the transcript level of the three cytokines had low SRs for the reference compound dexamethasone $(\mathrm{SR} \leq 50)$ and did not show $\mathrm{SR}>10$ for the other test compounds, suggesting that chemical action was rather non-specific for those parameters.

\section{Discussion}

The aim of the present study was to examine if an in vitro assay using isolated fish leukocytes is suitable to screen for immunotoxic potentials of environmental chemicals to fish and to discriminate those against chemicals with no known immunotoxic action. We exposed the leukocytes at non-cytotoxic concentrations in a short- ( $3 \mathrm{~h})$ and long-term $(19 \mathrm{~h})$ exposure scenario, each without and with previous LPS stimulation. As endpoints indicative of immunotoxic activity of the test compounds, we selected those parameters that were identified in a previous review $^{45}$ as the most frequently measured parameters in fish immunotoxicity studies: phagocytosis activity, oxidative burst activity and cytokine production. While the former two parameters could be stably measured in our in vitro assay, the cytokine transcript levels showed high interindividual variability what limits their value as immunotoxicity indicators but does not affect the overall conclusion of our study.

Differences between short- and long-term exposures were found particularly for the phagocytosis activity and the cytokine responses. In the case of the immune gene transcription the difference between short- and long-term 
a
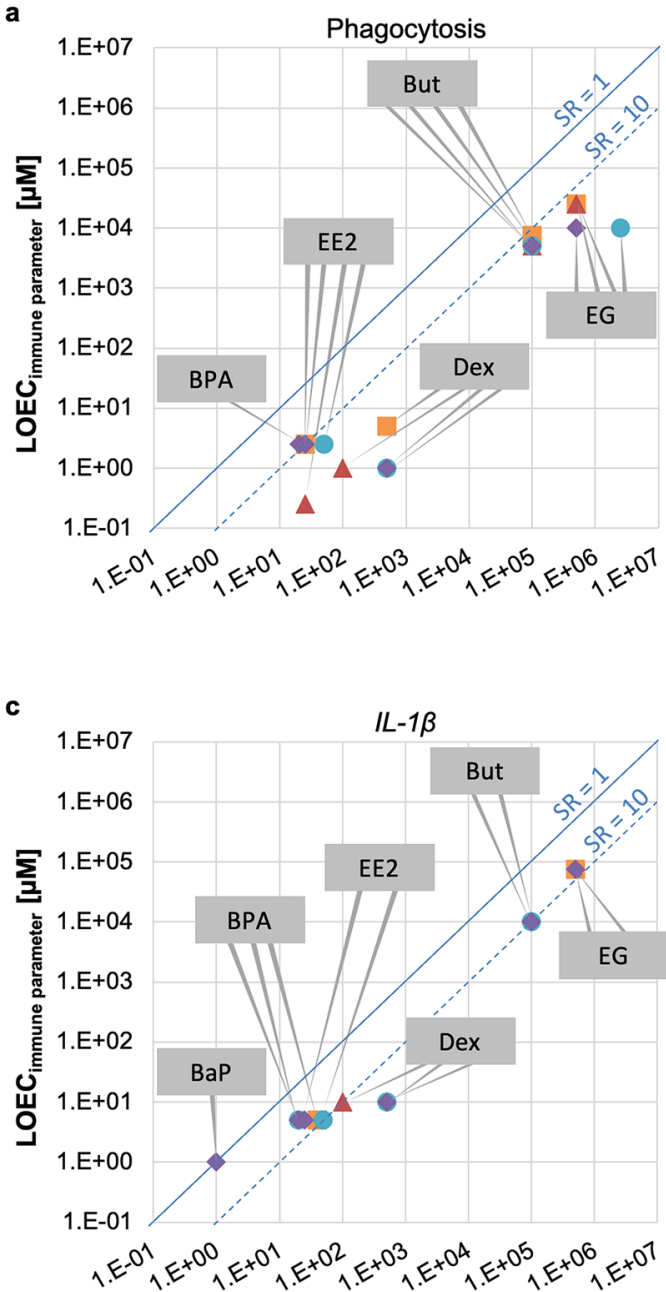

b

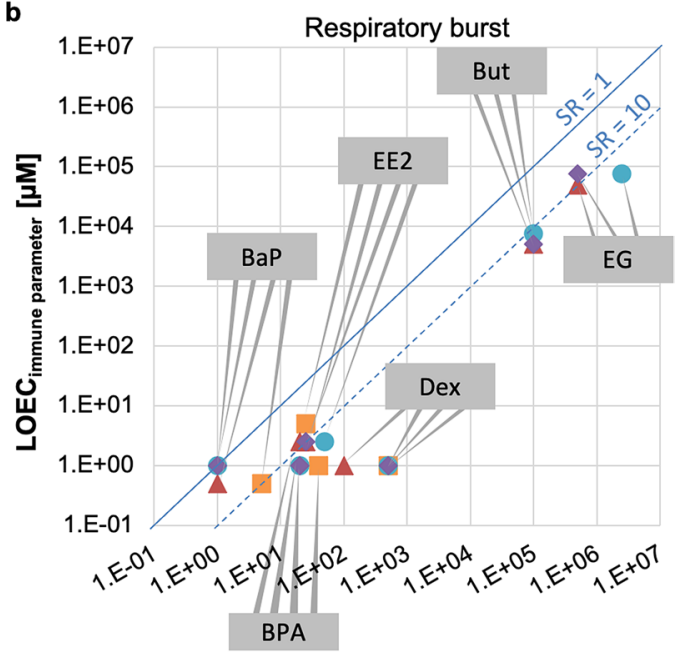

d

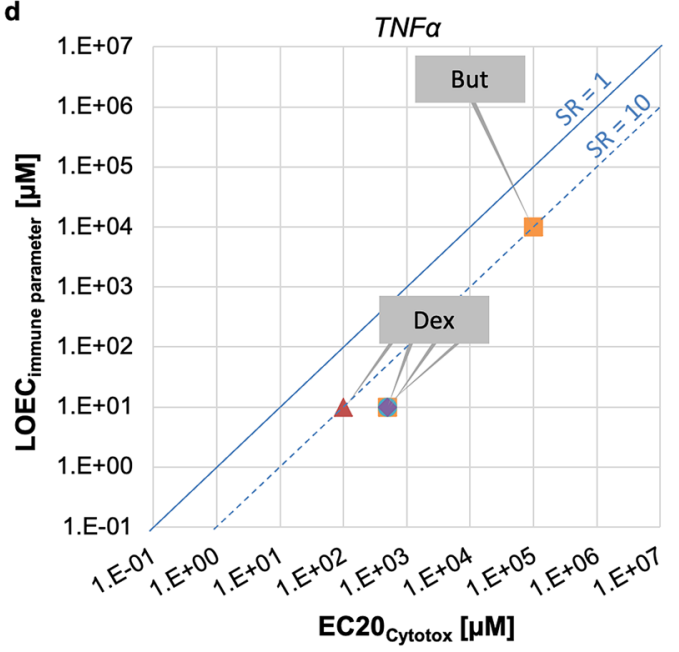

3 h no LPS

$\triangle 3 \mathrm{~h}$ plus LPS

- $19 \mathrm{~h}$ no LPS

- 19 h plus LPS

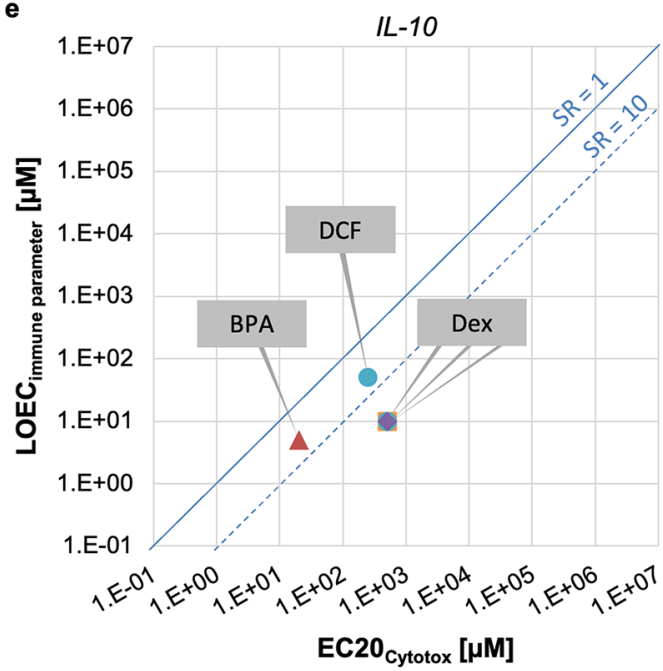

Figure 4. Comparison of the $\mathrm{LOEC}_{\text {immune parameter }}$ with the experimental cytotoxicity $\mathrm{EC} 20_{\mathrm{Cytotox}}$. The immunotoxicants are dexamethasone (Dex), diclofenac (DCF), benzo(a)pyrene (BaP), bisphenol A (BPA) and ethinylestradiol (EE2); non-immunotoxicants are ethylene glycol (EG) and butanol (But). The $\mathrm{LOEC}_{\text {immune parameter }}$ was not available for all endpoints and chemicals since only chemical-induced effect on immune parameter with a $p$ value $\leq 0.05$ were considered. $S R>10$ indicates specificity for chemical effects on immune parameter. $S R$ specific ratio, $L O E C$ lowest observed effect concentration, EC effect concentration. 


\begin{tabular}{|c|c|c|c|c|c|c|c|c|c|c|}
\hline \multirow[b]{2}{*}{$\begin{array}{l}\text { Test } \\
\text { chemical }\end{array}$} & \multicolumn{2}{|l|}{ Phagocytosis activity } & \multicolumn{2}{|c|}{ Respiratory burst activity } & \multicolumn{2}{|l|}{ IL-1 $\beta$ transcription } & \multicolumn{2}{|l|}{ TNFa transcription } & \multicolumn{2}{|l|}{ IL-10 transcription } \\
\hline & $\begin{array}{l}\text { Average } \\
\text { LOEC }_{\text {immune parameter }} \\
(\mu M)\end{array}$ & $\begin{array}{l}\text { Average } \\
\text { SR }\end{array}$ & $\begin{array}{l}\text { Average } \\
\text { LOEC } \mathrm{immune} \mathrm{parameter}_{(\mu \mathrm{M})}\end{array}$ & $\begin{array}{l}\text { Average } \\
\text { SR }\end{array}$ & $\begin{array}{l}\text { Average } \\
\text { LOEC }_{\text {immune parameter }} \\
(\mu \mathrm{M})\end{array}$ & $\begin{array}{l}\text { Average } \\
\text { SR }\end{array}$ & $\begin{array}{l}\text { Average } \\
\text { LOEC } \mathrm{C}_{\text {immune parameter }} \\
(\mu \mathrm{M})\end{array}$ & $\begin{array}{l}\text { Average } \\
\text { SR }\end{array}$ & $\begin{array}{l}\text { Average } \\
\text { LOEC }_{\text {immune parameter }} \\
(\mu \mathrm{M})\end{array}$ & $\begin{array}{l}\text { Average } \\
\text { SR }\end{array}$ \\
\hline $\begin{array}{l}\text { Dexa- } \\
\text { methasone } \\
\text { (Dex) }\end{array}$ & 2 & 300 & 1 & 400 & 10 & 37 & 10 & 40 & 10 & 50 \\
\hline $\begin{array}{l}\text { Diclofenac } \\
\text { (DCF) }\end{array}$ & \multicolumn{2}{|l|}{ n.d } & \multicolumn{2}{|l|}{ n.d } & \multicolumn{2}{|l|}{ n.d } & \multicolumn{2}{|l|}{ n.d } & 50 & 5 \\
\hline $\begin{array}{l}\text { Benzo(a) } \\
\text { pyrene } \\
(\mathrm{BaP}) \\
\end{array}$ & \multicolumn{2}{|l|}{ n.d } & 0.75 & 3.5 & 1 & 1 & \multicolumn{2}{|l|}{ n.d } & \multicolumn{2}{|l|}{ n.d } \\
\hline $\begin{array}{l}\text { Bisphenol } \\
\text { A (BPA) }\end{array}$ & 2.5 & 8 & 1.4 & 22 & 5 & 5 & \multicolumn{2}{|l|}{ n.d } & 5 & 4 \\
\hline \begin{tabular}{l|} 
Ethinyle- \\
stradiol \\
(EE2) \\
\end{tabular} & 2 & 35 & 3 & 11 & 5 & 7.5 & \multicolumn{2}{|l|}{ n.d } & \multicolumn{2}{|l|}{ n.d } \\
\hline $\begin{array}{l}\text { Ethylene } \\
\text { glycol (EG) }\end{array}$ & 17,500 & 85 & 66,667 & 17 & 75,000 & 7 & \multicolumn{2}{|l|}{ n.d } & \multicolumn{2}{|l|}{ n.d } \\
\hline $\begin{array}{l}\text { Butanol } \\
\text { (But) }\end{array}$ & 5,625 & 18 & 5,833 & 18 & 10,000 & 10 & 10,000 & 10 & n.d & \\
\hline
\end{tabular}

Table 4. Average LOEC $_{\text {immune parameter }}$ and average specific ratios (SR) for the immune parameters. The averages are derived from the values for short- and long-term exposure, each without and with LPS. n.d. not determinable, $S R$ specific ratio, LOEC lowest observed effect concentration.

exposures is probably due to biological mechanisms such as the involvement of different signaling pathways: for instance, time-dependent differences of the immunomodulating effects of ER-ligands have been reported for carp leukocytes. The time dependency may relate to the differential activation of (fast) non-genomic and (slow) genomic signaling pathways ${ }^{70}$. The effects seen for the phagocytosis activity are likely due to a technical issue: after $3 \mathrm{~h}$ of bead-exposure the percentage of phagocytosis-active cells in the total cell population was still very low and this translated into an instable measurement signal. After $19 \mathrm{~h}$ the percentage of phagocytosis-active cells had clearly increased, giving rise to a more stable signal.

The LPS-treatment of the leukocytes caused stimulation of the phagocytosis, respiratory burst activity and cytokine transcripts. Our findings of the LPS effects on the immune parameters are in line with results of other studies and reflect the stimulatory action of bacterial antigens on the immune cells ${ }^{71-80}$. Thus, LPS treatment could serve as positive and quality control for the validity of cell isolations (see "Data analysis").

The reference compound, dexamethasone, is an activator of the glucocorticoid receptor (GR) pathway. In our experiments, dexamethasone induced the expected responses. Regulation of GR by glucocorticoids in fish leukocytes has been demonstrated previously ${ }^{81,82}$. The significant inhibition of phagocytosis and respiratory burst activity observed in our study is in line with findings of other studies (e.g. ${ }^{31-33,83-85}$ ). For the transcript levels of the cytokines we observed a reduction of the pro-inflammatory $I L-1 \beta$ and $T N F \alpha$, together with a significant stimulation of the anti-inflammatory $I L-10$. The anti-inflammatory IL-10 is mainly involved in the attenuation of activated immune responses, in contrast to the pro-inflammatory cytokines ${ }^{86-90}$ thus, the observed opposite reaction patterns of the pro- and anti-inflammatory cytokines were to be expected. Together with this LPS results the findings from the dexamethasone experiments confirm the validity of the in vitro assay as performed in the present study.

Ethinylestradiol and bisphenol A displayed immunomodulating activities in the in vitro leukocyte assay. In line with our findings, these two estrogen-active compounds were found to influence the immune system of fish in a number of previous studies ${ }^{28,91-97}$. They mediate their effects probably via estrogen receptors (ER), which are known to be expressed in fish immune cells ${ }^{27,70,95,96,98}$.

Benzo(a)pyrene significantly stimulated the respiratory burst activity and significantly inhibited the transcription of $I L-1 \beta$ in the in vitro immuno-assay. Benzo(a)pyrene has a well-documented immunomodulating activity in fish including rainbow trout ${ }^{16-18}$. Its MoA involves the activation of the arylhydrocarbon receptor (AhR) which is a central regulator of various immune pathways and functions ${ }^{99}$ and known to be expressed in fish leukocytes ${ }^{100-102}$. Moreover, our findings on the immunomodulating properties of selected ER and AhR ligands in isolated trout leukocytes are corroborated by findings on ER- and AhR-mediated effects in other fish species such as sea bream, rare minnow and carp cant, $^{22,103-105}$.

Diclofenac had a weak effect in our in vitro immuno-assay. This was unexpected since diclofenac is a widely used pain killer with anti-inflammatory and immunosuppressant properties (e.g. ${ }^{106}$ ). Studies with fish demonstrated that it indeed modifies the expression level of cyclooxygenase (COX) and further immune parameters ${ }^{30,32,107}$. Nevertheless, evidence from mammalian studies suggest that diclofenac may not directly interfere with phagocytotic and respiratory activity. In cultured mice macrophages, COX inhibitors such as diclofenac enhanced zymosan-stimulated phagocytosis but had only a minor effect on the respiratory burst ${ }^{108}$. Neumüller and Tohidast-Akrad ${ }^{109}$ found only a slight increase in phagocytosis activity after exposing human peripheral blood leucocytes to diclofenac. In an invertebrate species, the freshwater mussel Elliptio complanate, no correlation between the effect of diclofenac on COX and phagocytosis could detected ${ }^{110}$. The finding that diclofenac had only a weak effect in our leukocyte assay highlights how important it is to consider the application domain of an 
assay: the assay used in the present study appear to be well able to screen for chemicals such as dexamethasone, ethinylestradiol, bisphenol A or benzo(a)pyrene that exert their immunological activity through receptors, but it may be less suitable for chemicals such a diclofenac which modulate the immune cells through other MoA.

The non-immunotoxicants, butanol and ethylene glycol, induced significant responses of at least some of the immune parameters. We tested a third baseline toxicant, 1,2,4-TCB, which was retrospectively excluded from the study. Due to its high volatility, the active concentration of TCB in the assay was difficult to control. Nevertheless, TCB, like butanol and ethylene glycol, evoked reactions in the immuno-assay (Supplementary Material S10). The observation that these baseline toxicants with no known immune activity still induce responses of the immune parameters in the in vitro leukocyte assay is in contradiction to our original expectation that the assay would discriminate between immunotoxicants and non-immunotoxicants. On the contrary, the in vitro assay would falsely classify ethylene glycol, butanol and TCB as potential immunotoxicants. It is acceptable that a screening assay produces false positive classifications, but the question is what percentage of false positives is acceptable? A too high percentage would disqualify the assay. On the basis of our study this question cannot be conclusively answered. It would need an extended testing of additional chemicals to conclude on the specificity of the in vitro fish leukocyte assay.

Is there a possible explanation for this lack of discrimination between immunotoxicants and non-immunotoxicants by the in vitro assay? The simplest explanation would be that we tested at concentrations that cause cytotoxicity. This, however, does not apply since we selected non-cytotoxic concentrations. Thus, other mechanisms must be responsible for the immunological activities of low concentrations of narcotic chemicals in the leukocyte assay. The assumption is supported by our in silico modeling as the SR for the non-immunotoxicants indicated a rather specific but not a cytotoxicity-driven action. Since we did not find any indication in the literature that those chemicals act via direct interference with immune system components, the observed effects might be rather based on an indirect action. Baseline or narcotic toxicity arises from the non-specific intercalation of these chemicals into the (phospho-)lipid layers of biological membranes thereby interfering with their normal functioning ${ }^{111}$. At high concentrations the chemical-induced disturbances lead to the loss of the barrier function of the cell membrane, eventually resulting in cell death. At low concentrations, the induced alterations of the cell membrane might be subtle but sufficient to cause osmotic stress to the cell and, associated with this, the modulation of cell membrane-associated signaling cascades such as ERK (extracellular signal-regulated kinases), JNK (c-Jun N-terminal kinase), MAPK (mitogen-activated protein kinase) or NFAT5 (Nuclear factor of activated T-cells 5) ${ }^{112-114}$. These signaling cascades function as stress sensors of the cell ${ }^{115-117}$ and they often converge with NF- $\kappa$ B (Nuclear factor kappa-light-chain-enhancer of activated B-cells) signaling. NF- $\kappa$ B is involved in the cellular stress response ${ }^{117}$ but at the same time is a central regulator of cellular immune functions ${ }^{118-120}$. Besides, cell membrane disturbances can activate the heat shock/chaperone systems which can modulate immune pathways ${ }^{121}$ or it may affect special regions of the cell membrane, the so-called lipid rafts. Lipid rafts were shown to be important organizing elements for immune signaling receptors ${ }^{122}$. Hence, the observed immune effects of the non-immunotoxicants may be due to indirect mechanisms mediated via a non-specific disturbance of the membrane rather than via specific and targeted immunotoxic MoAs. In the present study, only three narcotics were tested thus, the aforementioned considerations are highly speculative, but it may be worthwhile to investigate the suggested mechanism in future studies.

In conclusion, the present study provides a systematic evaluation of a potential fish immunotoxicity screening assay. A set of test compounds containing non-immunotoxic chemicals and toxicants with different modes of immunotoxic action were assessed under the same test conditions using identical effect parameters. From the results it appears that the in vitro fish leukocyte assay, as performed in the present study, has only a limited capacity for discriminating between immunotoxicants and non-immunotoxicants. Thus, this assay is not suitable as "stand alone assay" for immunotoxicity screening. Since the fish immune system is too complex to be represented by only one assay, it will need a battery of complementary assays $\left(\mathrm{cf}^{34}\right)$, as it is realized in the guidelines for human immunotoxicity testing ${ }^{123}$. To identify a test battery for fish immunotoxicity screening the systematic evaluation as conducted in the present study needs to be applied to further candidate parameters and assays.

Received: 5 August 2020; Accepted: 22 January 2021

Published online: 04 February 2021

\section{References}

1. Graham, A. L. et al. Fitness correlates of heritable variation in antibody responsiveness in a wild mammal. J. Sci. 330, 662-665 (2010).

2. Graham, A. L. et al. Fitness consequences of immune responses: Strengthening the empirical framework for ecoimmunology. Funct. Ecol. 25, 5-17 (2011).

3. Owens, I. P. F. \& Wilson, K. Immunocompetence: A neglected life history trait or conspicuous red herring?. Trends Ecol. Evol. 14, 170-172 (1999).

4. Selgrade, M. K. Immunotoxicity: The risk is real. Toxicol. Sci. 100, 328-332 (2007).

5. Acevedo-Whitehouse, K. \& Duffus, A. L. J. Effects of environmental change on wildlife health. Philos. Trans. R. Soc. B Biol. Sci. 364, 3429-3438 (2009).

6. Ali, A. O. et al. The effects of oil exposure on peripheral blood leukocytes and splenic melano-macrophage centers of Gulf of Mexico fishes. Mar. Pollut. Bull. 79, 87-93 (2014).

7. Arkoosh, M. R. et al. Effect of pollution on fish diseases: Potential impacts on salmonid populations. J. Aquat. Anim. Health 10, 182-190 (1998).

8. Arkoosh, M. R., Clemons, E., Huffman, P. \& Kagley, A. N. Increased susceptibility of juvenile chinook salmon to vibriosis after exposure to chlorinated and aromatic compounds found in contaminated urban estuaries. J. Aquat. Anim. Health 13, 257-268 (2001). 
9. Arkoosh, M. R. et al. Dietary exposure to a binary mixture of polybrominated diphenyl ethers alters innate immunity and disease susceptibility in juvenile Chinook salmon (Oncorhynchus tshawytscha). Ecotox. Environ. Safe. 163, 96-103 (2018).

10. Clifford, M. A., Eder, K. J., Werner, I. \& Hedrick, R. P. Synergistic effects of esfenvalerate and infectious hematopoietic necrosis virus on juvenile chinook salmon mortality. Environ. Toxicol. Chem. 24, 1766-1772 (2005).

11. McElroy, A. E. et al. Spatial patterns in markers of contaminant exposure, glucose and glycogen metabolism, and immunological response in juvenile winter flounder (Pseudoplueronectes americanus). Comp. Biochem. Physiol. Part D Genom. Proteom. 14, 53-65 (2015).

12. Bailey, C., Wernickevon Siebenthal, E., Rehberger, K. \& Segner, H. Transcriptomic analysis of the impacts of ethinylestradiol (EE2) and its consequences for proliferative kidney disease outcome in rainbow trout (Oncorhynchus mykiss). Comp. Biochem. Physiol. C Toxicol. Pharmacol. 222, 31-48 (2019).

13. Poulin, R. Toxic pollution and parasitism in freshwater fish. Parasitol. Today 8, 58-61 (1992).

14. Arkoosh, M. R., Clemons, E., Myers, M. \& Casillas, E. Suppression of B-cell mediated immunity in juvenile chinook salmon (Oncorhynchus tshawytscha) after exposure to either a polycyclic aromatic hydrocarbon or to polychlorinated biphenyls. Immunopharmacol. Immunotoxicol. 16, 293-314 (1994).

15. Arkoosh, M. R. et al. Dietary exposure to individual polybrominated diphenyl ether congeners BDE- 47 and BDE-99 alters innate immunity and disease susceptibility in juvenile chinook salmon. Environ. Sci. Technol. 49, 6974-6981 (2015).

16. Carlson, E. A., Li, Y. \& Zelikoff, J. T. The japanese medaka (Oryzias latipes) model: Applicability for investigating the immunosuppressive effects of the aquatic pollutant benzo[a]pyrene (BaP). Mar. Environ. Res. 54, 565-568 (2002).

17. Carlson, E. A., Li, Y. \& Zelikoff, J. T. Suppressive effects of benzo[a]pyrene upon fish immune function: Evolutionarily conserved cellular mechanisms of immunotoxicity. Mar. Environ. Res. 58, 731-734 (2004).

18. Carlson, E. A., Li, Y. \& Zelikoff, J. T. Benzo[a]pyrene-induced immunotoxicity in japanese medaka (Oryzias latipes): Relationship between lymphoid CYP1A activity and humoral immune suppression. Toxicol. Appl. Pharmacol. 201, 40-52 (2004).

19. Curtis, L. R. et al. Transcriptional changes in innate immunity genes in head kidneys from Aeromonas salmonicida-challenged rainbow trout fed a mixture of polycyclic aromatic hydrocarbons. Ecotox. Environ. Safe. 142, 157-163 (2017).

20. Hur, D., Jeon, J. K. \& Hong, S. Analysis of immune gene expression modulated by benzo[a]pyrene in head kidney of olive flounder (Paralichthys olivaceus). Comp. Biochem. Physiol. B Biochem. Mol. Biol. 165, 49-57 (2013).

21. Reynaud, S. \& Deschaux, P. The effects of polycyclic aromatic hydrocarbons on the immune system of fish: A review. Aquat. Toxicol. 77, 229-238 (2006).

22. Cabas, I. et al. 17 alpha-ethynylestradiol alters the immune response of the teleost gilthead seabream (Sparus aurata L.) both in vivo and in vitro. Dev. Comp. Immunol. 36, 547-556 (2012).

23. Cuesta, A. et al. Effect of sex-steroid hormones, testosterone and estradiol, on humoral immune parameters of gilthead seabream. Fish Shellf. Immun. 23, 693-700 (2007).

24. Jin, Y., Chen, R., Liu, W. \& Fu, Z. Effect of endocrine disrupting chemicals on the transcription of genes related to the innate immune system in the early developmental stage of zebrafish (Danio rerio). Fish Shellf. Immun. 28, 854-861 (2010).

25. Milla, S., Depiereux, S. \& Kestemont, P. The effects of estrogenic and androgenic endocrine disruptors on the immune system of fish: A review. Ecotoxicology 20, 305-319 (2011).

26. Shelley, L. K., Osachoff, H. L., van Aggelen, G. C., Ross, P. S. \& Kennedy, C. J. Alteration of immune function endpoints and differential expression of estrogen receptor isoforms in leukocytes from 17 beta-estradiol exposed rainbow trout (Oncorhynchus mykiss). Gen. Comp. Endocr. 180, 24-32 (2013).

27. Shelley, L. K., Ross, P. S. \& Kennedy, C. J. The effects of an in vitro exposure to 17 beta-estradiol and nonylphenol on rainbow trout (Oncorhynchus mykiss) peripheral blood leukocytes. Comp. Biochem. Physiol. C Toxicol. Pharmacol. 155, 440-446 (2012).

28. Thilagam, H., Gopalakrishnan, S., Bo, J. \& Wang, K. J. Effect of 17 beta-estradiol on the immunocompetence of japanese sea bass (Lateolabrax japonicus). Environ. Toxicol. Chem. 28, 1722-1731 (2009).

29. Wenger, M., Sattler, U., Goldschmidt-Clermont, E. \& Segner, H. 17 beta-estradiol affects the response of complement components and survival of rainbow trout (Oncorhynchus mykiss) challenged by bacterial infection. Fish Shellf. Immun. 31, 90-97 (2011).

30. Hoeger, B., Kollner, B., Dietrich, D. R. \& Hitzfeld, B. Water-borne diclofenac affects kidney and gill integrity and selected immune parameters in brown trout (Salmo trutta f. fario). Aquat. Toxicol. 75, 53-64 (2005).

31. Lovy, J., Speare, D. J., Stryhn, H. \& Wright, G. M. Effects of dexamethasone on host innate and adaptive immune responses and parasite development in rainbow trout Oncorhynchus mykiss infected with Loma salmonae. Fish Shellf. Immun. 24, 649-658 (2008).

32. Ribas, J. L., Zampronio, A. R. \& Silva de Assis, H. C. Effects of trophic exposure to diclofenac and dexamethasone on hematological parameters and immune response in freshwater fish. Environ. Toxicol. Chem. 35, 975-982 (2016).

33. Salas-Leiton, E. et al. Dexamethasone modulates expression of genes involved in the innate immune system, growth and stress and increases susceptibility to bacterial disease in senegalese sole (Solea senegalensis Kaup, 1858). Fish Shellf. Immun. 32, 769-778 (2012).

34. Zelikoff, J. T. et al. Immunotoxicity biomarkers in fish: Development, validation and application for field studies and risk assessment. Hum. Ecol. Risk Assess. 8, 253-263 (2002).

35. Boverhof, D. R. et al. Approaches and considerations for the assessment of immunotoxicity of environmental chemicals: A workshop summary. Regul. Toxicol. Pharmacol. 68, 96-107 (2014).

36. Luster, M. I. \& Gerberick, G. F. Immunotoxicology testing: Pat and future. Methods Mol. Biol. 598, 3-13 (2010).

37. Hinton, D. M. US FA "Redbook II" Immunotoxicity testing guidelines and research in immunotoxicity evaluations of food chemicals and new food proteins. Toxicol. Pathol. 28, 467-478 (2000).

38. Krewski, D. et al. Toxicity testing in the 21 st century: A vision and a strategy. J. Toxicol. Environ. Health B Crit. Rev. 13, 51-138 (2010).

39. Kavlock, R. et al. Update on EPA's ToxCast program: Providing high throughput decision support tools for chemical risk management. Chem. Res. Toxicol. 25, 1287-1302 (2012).

40. Corsini, E. \& Roggen, E. L. Overview of in vitro assessment of immunotoxicity. Curr. Opin. Toxicol. 5, 13-18 (2017).

41. Hartung, T. \& Corsini, E. Immunotoxicology: Challenges in the 21 st century and in vitro opportunities. Altern. Anim. Ex. 30, 411-426 (2013).

42. Luebke, R. Immunotoxicant screening and prioritization in the twenty-first century. Toxicol. Pathol. 40, 294-299 (2012).

43. Gennari, A. et al. The use of in vitro systems for evaluating immunotoxicity: The report and recommendations of an ECVAM workshop. J. Immunotoxicol. 2, 61-83 (2005).

44. Galbiati, V., Mitjans, M. \& Corsini, E. Present and future of in vitro immunotoxicology in drug development. J. Immunotoxicol. 7, 255-267 (2010).

45. Rehberger, K., Werner, I., Hitzfeld, B., Segner, H. \& Baumann, L. 20 years of fish immunotoxicology-what we know and where we are. Crit. Rev. Toxicol. 47, 509-535 (2017).

46. Randelli, E., Buonocore, F. \& Scapigliati, G. Cell markers and determinants in fish immunology. Fish Shellf. Immun. 25, 326-340 (2008).

47. Fournier, M., Cyr, D., Blakley, B., Boermans, H. \& Brousseau, P. Phagocytosis as a biomarker of immunotoxicity in wildlife species exposed to environmental xenobiotics. Am. Zool. 40, 412-420 (2000).

48. Zou, J. \& Secombes, C. J. The function of fish cytokines. Biology 5, e23 (2016). 
49. Koellner, B., Wasserrab, B., Kotterba, G. \& Fischer, U. Evaluation of immune functions of rainbow trout (Oncorhynchus mykiss) — how can environmental influences be detected?. Toxicol. Lett. 131, 83-95 (2002).

50. Judson, R. et al. Analysis of the effects of cell stress and cytotoxicity on in vitro assay activity across a diverse chemical and assay space. Toxicol. Sci. 152, 323-339 (2016).

51. Escher, B. I., Glauch, L., König, M., Mayer, P. \& Schlichting, R. Baseline toxicity and volatility cutoff in reporter gene assays used for high-throughput screening. Chem. Res. Toxicol. 32, 1646-1655 (2019).

52. Escher, B., Henneberger, L., König, M., Schlichting, R. \& Fischer, F. C. Cytotoxicity burst? Differentiating specific from nonspecific effects in Tox21 in vitro reporter gene assays. Environ. Health. Persp. 128, 077007 (2020).

53. Garduño, R. A. \& Kay, W. W. In Analytical Techniques*** Col 3 (eds Mommsen, T. P. \& Hochachka, P. W.) 327-339 (Elsevier Science, New York, 1994).

54. Braun-Nesje, R., Bertheussen, K., Kaplan, G. \& Seljelid, R. Salmonid macrophages: Separation, in vitro culture and characterization. J. Fish Dis. 4, 141-151 (1981).

55. MacKenzie, S. A., Roher, N., Boltana, S. \& Goetz, F. W. Peptidoglycan, not endotoxin, is the key mediator of cytokine gene expression induced in rainbow trout macrophages by crude LPS. Mol. Immunol. 47, 1450-1457 (2010).

56. Lilius, H., Hastbacka, T. \& Isomaa, B. A combination of fluorescent probes for evaluation of cytotoxicity and toxic mechanisms in isolated rainbow trout hepatocytes. Toxicol. In Vitro 10, 341-348 (1996).

57. Harford, A. J., O'Halloran, K. \& Wright, P. F. Flow cytometric analysis and optimisation for measuring phagocytosis in three Australian freshwater fish. Fish Shellf. Immun. 20, 562-573 (2006).

58. Castro, R. \& Tafalla, C. In Mucosal Health in Aquaculture (ed. Peatman, E.) 3-54 (Academic Press, New York, 2015).

59. Li, J. et al. B lymphocytes from early vertebrates have potent phagocytic and microbicidal abilities. Nat. Immunol. 7, 1116-1124 (2006).

60. Ronneseth, A., Ghebretnsae, D. B., Wergeland, H. I. \& Haugland, G. T. Functional characterization of IgM+ B cells and adaptive immunity in lumpfish (Cyclopterus lumpus L.). Dev. Comp. Immunol. 52, 132-143 (2015).

61. Zhang, Y. A. et al. IgT, a primitive immunoglobulin class specialized in mucosal immunity. Nat. Immunol. 11, 827-835 (2010).

62. Rymuszka, A. \& Adaszek, L. Cytotoxic effects and changes in cytokine gene expression induced by microcystin-containing extract in fish immune cells—an in vitro and in vivo study. Fish Shellf. Immun. 34, 1524-1532 (2013).

63. Fischer, F. C. et al. Modeling exposure in the Tox21 in vitro bioassays. Chem. Res. Toxicol. 30, 1197-1208 (2017).

64. Fischer, F. C., Cirpka, O., Goss, K. U., Henneberger, L. \& Escher, B. I. Application of experimental polystyrene partition constants and diffusion coefficients to predict the sorption of organic chemicals to well plates in in vitro bioassays. Environ. Sci. Technol. 52, 13511-13522 (2018).

65. Maeder, V., Escher, B., Scheringer, M. \& Hungerbühler, K. Toxic ratio as an indicator of the intrinsic toxicity in the assessment of persistent, bioaccumulative, and toxic chemicals. Environ. Sci. Technol. 38, 3659-3666 (2004).

66. Escher, B. I., Braun, G. \& Zarfl, C. Exploring the concepts of concentration addition and independent action using a linear loweffect mixture model. Environ. Toxicol. Chem. 39, 2552-2559 (2020).

67. Harrel, F. E. Regression Modelling Strategies, Vol. 20 (Springer, Berlin, 2001).

68. Team, R. C. (ISBN3-900051-07-0 https://www.R-project.org, 2017).

69. Kuhn, M. et al. Contrast: A collection of contrast methods. $R$ Package Version 0.21. https://CRAN.R-project.org/package=contr ast (2016).

70. Szwejser, E. et al. A role for multiple estrogen receptors in immune regulation of common carp. Dev. Comp. Immunol. 66, 61-72 (2017).

71. Bo, J. et al. Benzo[a]pyrene modulation of acute immunologic responses in red sea bream pretreated with lipopolysaccharide. Environ. Toxicol. 29, 517-525 (2014).

72. Sakai, M. Current research status of fish immunostimulants. Aquaculture 172, 63-92 (1999).

73. Chettri, J. K., Raida, M. K., Holten-Andersen, L., Kania, P. W. \& Buchmann, K. PAMP induced expression of immune relevant genes in head kidney leukocytes of rainbow trout (Oncorhynchus mykiss). Dev. Comp. Immunol. 35, 476-482 (2011).

74. Engelsma, M. Y., Stet, R. J., Schipper, H. \& Verburg-van Kemenade, B. M. Regulation of interleukin 1 beta RNA expression in the common carp, Cyprinus carpio L. Dev. Comp. Immunol. 25, 195-203 (2001).

75. MacKenzie, S. et al. Transcriptional analysis of LPS-stimulated activation of trout (Oncorhynchus mykiss) monocyte/macrophage cells in primary culture treated with cortisol. Mol. Immunol. 43, 1340-1348 (2006).

76. MacKenzie, S. A., Planas, J. V. \& Goetz, F. W. LPS-stimulated expression of a tumor necrosis factor-alpha mRNA in primary trout monocytes and in vitro differentiated macrophages. Dev. Comp. Immunol. 27, 393-400 (2003).

77. Savan, R., Igawa, D. \& Sakai, M. Cloning, characterization and expression analysis of interleukin-10 from the common carp, Cyprinus carpio L.. Eur. J. Biochem. 270, 4647-4654 (2003).

78. Secombes, C. J., Bird, S., Cunningham, C. \& Zou, J. Interleukin-1 in fish. Fish Shellf. Immun. 9, 335-343 (1999).

79. Seppola, M., Larsen, A. N., Steiro, K., Robertsen, B. \& Jensen, I. Characterisation and expression analysis of the interleukin genes, IL-1beta, IL-8 and IL-10, in Atlantic cod (Gadus morhua L.). Mol. Immunol. 45, 887-897 (2008).

80. Zhang, D. C., Shao, Y. Q., Huang, Y. Q. \& Jiang, S. G. Cloning, characterization and expression analysis of interleukin-10 from the zebrafish (Danio rerion). J. Biochem. Mol. Biol. 38, 571-576 (2005).

81. Maule, A. G. \& Schreck, C. B. Stress and cortisol treatment changed affinity and number of glucocorticoid receptors in leukocytes and gill of coho salmon. Gen. Comp. Endocr. 84, 83-93 (1991).

82. Weyts, F. A., Verburg-van Kemenade, B. M. \& Flik, G. Characterisation of glucocorticoid receptors in peripheral blood leukocytes of Carp, Cyprinus carpioL.. Gen. Comp. Endocr. 111, 1-8 (1998).

83. Harris, J. \& Bird, D. J. Modulation of the fish immune system by hormones. Vet. Immunol. Immunop. 77, 163-176 (2000).

84. Lindenstrom, T. \& Buchmann, K. Dexamethasone treatment increases susceptibility of rainbow trout, Oncorhynchus mykiss (Walbaum), to infections with Gyrodactylus derjavini Mikailov. J. Fish Dis. 21, 29-38 (1998).

85. Nielsen, C. V. \& Buchmann, K. Increased susceptibility of atlantic salmon Salmo salar to infections with Gyrodactylus derjavini induced by dexamethasone bath treatment. J. Helminthol. 77, 65-68 (2003).

86. Cunha, F. Q., Moncada, S. \& Liew, F. Y. Interleukin-10 (IL-10) inhibits the induction of nitric oxide synthase by interferon-gamma in murine macrophages. Biochem. Biophys. Res. Commun. 182, 1155-1159 (1992).

87. Fiorentino, D. F., Zlotnik, A., Mosmann, T. R., Howard, M. \& O'Garra, A. IL-10 inhibits cytokine production by activated macrophages. J. Immunol. 147, 3815-3822 (1991).

88. Moore, K. W., de Waal Malefyt, R., Coffman, R. L. \& O'Garra, A. Interleukin-10 and the interleukin-10 receptor. Annu. Rev. Immunol. 19, 683-765 (2001).

89. Moore, K. W., O'Garra, A., de Waal Malefyt, R., Vieira, P. \& Mosmann, T. R. Interleukin-10. Annu. Rev. Immunol. 11, 165-190 (1993).

90. Mosmann, T. R. Properties and functions of interleukin-10. Adv. Immunol. 56, 1-26 (1994).

91. Cabas, I. et al. Dietary intake of 17 alpha-ethinylestradiol promotes leukocytes infiltration in the gonad of the hermaphrodite gilthead seabream. Mol. Immunol. 48, 2079-2086 (2011).

92. Casanova-Nakayama, A. et al. Endocrine disrupting compounds: Can they target the immune system of fish?. Mar. Pollut. Bull. 63, 412-416 (2011). 
93. Seemann, F., Knigge, T., Olivier, S. \& Monsinjon, T. Exogenous 17 beta-oestradiol (E2) modifies thymus growth and regionalization in european sea bass Dicentrarchus labrax. J. Fish Biol. 86, 1186-1198 (2015).

94. Seemann, F., Knigge, T., Rocher, B., Minier, C. \& Monsinjon, T. 17 beta-estradiol induces changes in cytokine levels in head kidney and blood of juvenile sea bass (Dicentrarchus labrax, L., 1758). Mar. Environ. Res. 87-88, 44-51 (2013).

95. Rogers, J. A., Metz, L. \& Yong, V. W. Review: Endocrine disrupting chemicals and immune responses: A focus on bisphenol-A and its potential mechanisms. Mol. Immunol. 53, 421-430 (2013).

96. Yang, M. et al. The in vitro immune modulatory effect of bisphenol A on fish macrophages via estrogen receptor alpha and nuclear factor-kappaB signaling. Environ. Sci. Technol. 49, 1888-1895 (2015).

97. Yin, D. Q. et al. Immunotoxicity of bisphenol A to Carassius auratus lymphocytes and macrophages following in vitro exposure. J. Environ. Sci. 19, 232-237 (2007).

98. Casanova-Nakayama, A., von Siebenthal, E. W., Kropf, C., Oldenberg, E. \& Segner, H. Immune-specific expression and estrogenic regulation of the four estrogen receptor isoforms in female rainbow trout (Oncorhynchus mykiss). Int. J. Mol. Sci. 19, 931-918 (2018).

99. Quintana, F. J. The aryl hydrocarbon receptor: A molecular pathway for the environmental control of the immune response. Immunology 138, 183-189 (2013).

100. Nakayama, A., Riesen, I., Kollner, B., Eppler, E. \& Segner, H. Surface marker-defined head kidney granulocytes and B lymphocytes of rainbow trout express benzo[a]pyrene-inducible cytochrome P4501A protein. Toxicol. Sci. 103, 86-96 (2008).

101. Holen, E. \& Olsvik, P. A. Aryl hydrocarbon receptor protein and Cyp1A1 gene induction by LPS and phenanthrene in Atlantic cod (Gadus morhua) head kidney cells. Fish Shellf. Immun. 40, 384-391 (2014).

102. Song, J. Y. et al. Aryl hydrocarbon receptor signaling is functional in immune cells of rainbow trout (Oncorhynchus mykiss). Int. J. Mol. Sci. 21, 6323 (2020).

103. Gushiken, Y., Watanuki, H. \& Sakai, M. In vitro effect of carp phagocytic cells by bisphenol A and nonylphenol. Fish. Sci. 68, 178-183 (2002).

104. Tao, S. et al. Oxidative stress and immunotoxic effects of bisphenol A on the larvae of rare minnow Gobiocypris rarus. Ecotox. Environ. Safe. 124, 377-385 (2016).

105. Watanuki, H., Yamaguchi, T. \& Sakai, M. Suppression in function of phagocytic cells in common carp Cyprinus carpio L. injected with estradiol, progesterone or 11-ketotestosterone. Comp. Biochem. Physiol. C Toxicol. Pharmacol. 132, 407-413 (2002).

106. Skoutakis, V. A. et al. Review of diclofenac and evaluation of its place in therapy as a nonsteroidal antiinflammatory agent. Drug Intell. Clin. Pharm. 22, 850-859 (1988).

107. Mehinto, A. C., Hill, E. M. \& Tyler, C. R. Uptake and biological effects of environmentally relevant concentrations of the nonsteroidal anti-inflammatory pharmaceutical diclofenac in rainbow trout (Oncorhynchus mykiss). Environ. Sci. Technol. 44, 2176-2182 (2010)

108. Schnyder, J., Dewald, B. \& Baggioloni, M. Effects of cyclooxygenase inhibitors and prostaglandin E2 on macrophage activation in vitro. Prostaglandins 22, 411-421 (1981).

109. Neumüller, J. \& Tohidast-Akrad, M. Comparative in vitro investigations of the influence of mofebutazone, phenylbutazone and diclofenac on phagocytosis and respiratory burst of human peripheral blood leucocytes. Arzneim. Forsch. 44, 636 (1994).

110. Bouchard, B., Gagné, F., Fortier, M. \& Fournier, M. An in-situ study of the impacts of urban wastewater on the immune and reproductive systems of the freshwater mussel Elliptio complanata. Comp. Biochem. Physiol. C Toxicol. Pharmacol. 150, 132-140 (2009).

111. Van Wezel, A. \& Opperhuizen, A. Narcosis due to environmental-pollutants in aquatic organisms-residue-based toxicity, mechanisms, and membrane burdens. Crit. Rev. Toxicol. 25, 255-279 (1995).

112. Ip, Y. T. \& Davis, R. J. Signal transduction by the c-Jun N-terminal kinase (JNK)-from inflammation to development. Curr. Opin. Cell Biol. 10, 205-219 (1998).

113. Lee, F. S., Hagler, J., Chen, Z. J. \& Maniatis, T. Activation of the IкBa kinase complex by MEKK1, a kinase of the JNK pathway. Cell 88, 213-222 (1997).

114. Lopez-Rodriguez, C. et al. Bridging the NFAT and NF-kappaB families: NFAT5 dimerization regulates cytokine gene transcription in response to osmotic stress. Immunity 15, 47-58 (2001).

115. Los, D. A. \& Murata, N. Membrane fluidity and its roles in the perception of environmental signals. Biochim. Biophys. Acta Biomembr. 1666, 142-157 (2004).

116. Toth, M. E., Vigh, L. \& Santha, M. Alcohol stress, membranes, and chaperones. Cell Stress Chaperones 19, $299-309$ (2014).

117. Simmons, S. O., Fan, C.-Y. \& Ramabhadran, R. Cellular stress response pathway system as a sentinel ensemble in toxicological screening. Toxicol. Sci. 111, 202-225 (2009).

118. Baldwin, A. S. The NF-kappa B and I kappa B proteins: New discoveries and insights. Annu. Rev. Immunol. 14, 649-683 (1996).

119. Blackwell, T. S. \& Christman, J. W. The role of nuclear factor-kappa B in cytokine gene regulation. Am. J. Resp. Cell. Mol. 17, 3-9 (1997).

120. Vallabhapurapu, S. \& Karin, M. Regulation and function of NF-kappa B transcription factors in the immune system. Annu. Rev. Immunol. 27, 693-733 (2009).

121. Pockley, A. G. Heat shock proteins as regulators of the immune response. Lancet 362, 469-476 (2003).

122. Dykstra, M., Cherukuri, A., Sohn, H. W., Tzeng, S. J. \& Pierce, S. K. Location is everything: Lipid rafts and immune cell signaling. Annu. Rev. Immunol. 21, 457-481 (2003).

123. IPCS. Guidance for immunotoxicity risk assessment for chemicals. Geneva: World Health Organization. http://www.inchem.org/ documents/harmproj/harmproj/harmproj10.pdf. (2012).

124. Greenwood, A. K. et al. Multiple corticosteroid receptors in a teleost fish: Distinct sequences, expression patterns, and transcriptional activities. Endocrinology 144, 4226-4236 (2003)

125. Prunet, P., Sturm, A. \& Milla, S. Multiple corticosteroid receptors in fish: From old ideas to new concepts. Gen. Comp. Endocr. $147,17-23(2006)$.

126. Lemairegony, S., Lemaire, P. \& Pulsford, A. L. Effects of cadmium and beno(a)pyrene on the immune-system, gill ATPase and EROD activity of european sea bass dicentrarchus-labrax. Aquat. Toxicol. 31, 297-313 (1995).

127. Smith, D. A., Schurig, G. G., Smith, S. A. \& Holladay, S. D. The hemolytic plaque-forming cell assay in tilapia (Oreochromis niloticus) exposed to benzo[a]pyrene: Enhanced or depressed plaque formation depends on dosing schedule. Toxicol. Method. 9, 57-70 (1999).

128. Shved, N. et al. Challenge with 17 alpha-ethinylestradiol (EE2) during early development persistently impairs growth, differentiation, and local expression of IGF-I and IGF-II in immune organs of tilapia. Fish Shellf. Immun. 26, 524-530 (2009).

129. Hawliczek-Ignarski, A., Cenijn, P., Legler, J., Segner, H. \& Legradi, J. Mode of action assignment of chemicals using toxicogenomics: A case study with oxidative uncouplers. Front. Environ. Sci. 5(80), 81-14 (2017).

130. Casalegno, M. \& Sello, G. Quantitative aquatic toxicity prediction: Using group contribution and classification methods on polar and non-polar narcotics. J. Mol. Struc-Theochem. 727, 71-80 (2005).

131. Ramos, E. U., Vermeer, C., Vaes, W. H. J. \& Hermens, J. L. M. Acute toxicity of polar narcotics to three aquatic species (Daphnia magna, Poecilia reticulata and Lymnaea stagnalis) and its relation to hydrophobicity. Chemosphere 37, 633-650 (1998).

132. Verhaar, H. J., Solbe, J., Speksnijder, J., van Leeuwen, C. J. \& Hermens, J. L. Classifying environmental pollutants: Part 3. External validation of the classification system. Chemosphere 40, 875-883 (2000). 
133. Nendza, M. \& Wenzel, A. Discriminating toxicant classes by mode of action, 1. (Eco)toxicity profiles. Environ. Sci. Pollut. Res. 13, 192-203 (2006).

134. Schirmer, K. et al. Developing a list of reference chemicals for testing alternatives to whole fish toxicity tests. Aquat. Toxicol. 90, 128-137 (2008).

135. Verhaar, H. J. M., Vanleeuwen, C. J. \& Hermens, J. L. M. Classifying environmental-pollutants, 1. structure-activity-relationships for prediction of aquatic toxicity. Chemosphere 25, 471-491 (1992).

136. Garikipati, D. K., Gahr, S. A., Roalson, E. H. \& Rodgers, B. D. Characterization of rainbow trout myostatin-2 genes (rtMSTN-2a and-2b): Genomic organization, differential expression, and pseudogenization. Endocrinology 148, 2106-2115 (2007).

137. Kropf, C., Segner, H. \& Fent, K. ABC transporters and xenobiotic defense systems in early life stages of rainbow trout (Oncorhynchus mykiss). Comp. Biochem. Physiol. C Toxicol. Pharmacol. 185, 45-56 (2016).

138. Bailey, C., Segner, H., Casanova-Nakayama, A. \& Wahli, T. Who needs the hotspot? The effect of temperature on the fish host immune response to Tetracapsuloides bryosalmonae the causative agent of proliferative kidney disease. Fish Shellf. Immun. 63, 424-437 (2017).

\section{Acknowledgements}

The work was financially supported by the EU project SOLUTIONS \# 603437 and the Swiss Center for Applied Ecotoxicology (Eawag, Dübendorf, Switzerland).

\section{Author contributions}

Conceptualization: K.R., I.W., H.S. Methodology: K.R., A.S. Software: B.I.E., A.S. Formal analysis: K.R., B.I.E., A.S. Investigation: K.R. Resources: K.R., H.S. Data curation: K.R., A.S. Writing-original draft: K.R., H.S. Writing-review and editing: K.R., B.I.E., A.S., I.W., H.S. Visualization: K.R., B.I.E., A.S. Supervision: H.S. Project administration: K.R., I.W., H.S. Funding acquisition: H.S.

\section{Competing interests}

The authors declare no competing interests.

\section{Additional information}

Supplementary Information The online version contains supplementary material available at https://doi. org/10.1038/s41598-021-82711-5.

Correspondence and requests for materials should be addressed to K.R.

Reprints and permissions information is available at www.nature.com/reprints.

Publisher's note Springer Nature remains neutral with regard to jurisdictional claims in published maps and institutional affiliations.

(c) (i) Open Access This article is licensed under a Creative Commons Attribution 4.0 International cc) License, which permits use, sharing, adaptation, distribution and reproduction in any medium or format, as long as you give appropriate credit to the original author(s) and the source, provide a link to the Creative Commons licence, and indicate if changes were made. The images or other third party material in this article are included in the article's Creative Commons licence, unless indicated otherwise in a credit line to the material. If material is not included in the article's Creative Commons licence and your intended use is not permitted by statutory regulation or exceeds the permitted use, you will need to obtain permission directly from the copyright holder. To view a copy of this licence, visit http://creativecommons.org/licenses/by/4.0/.

(c) The Author(s) 2021 